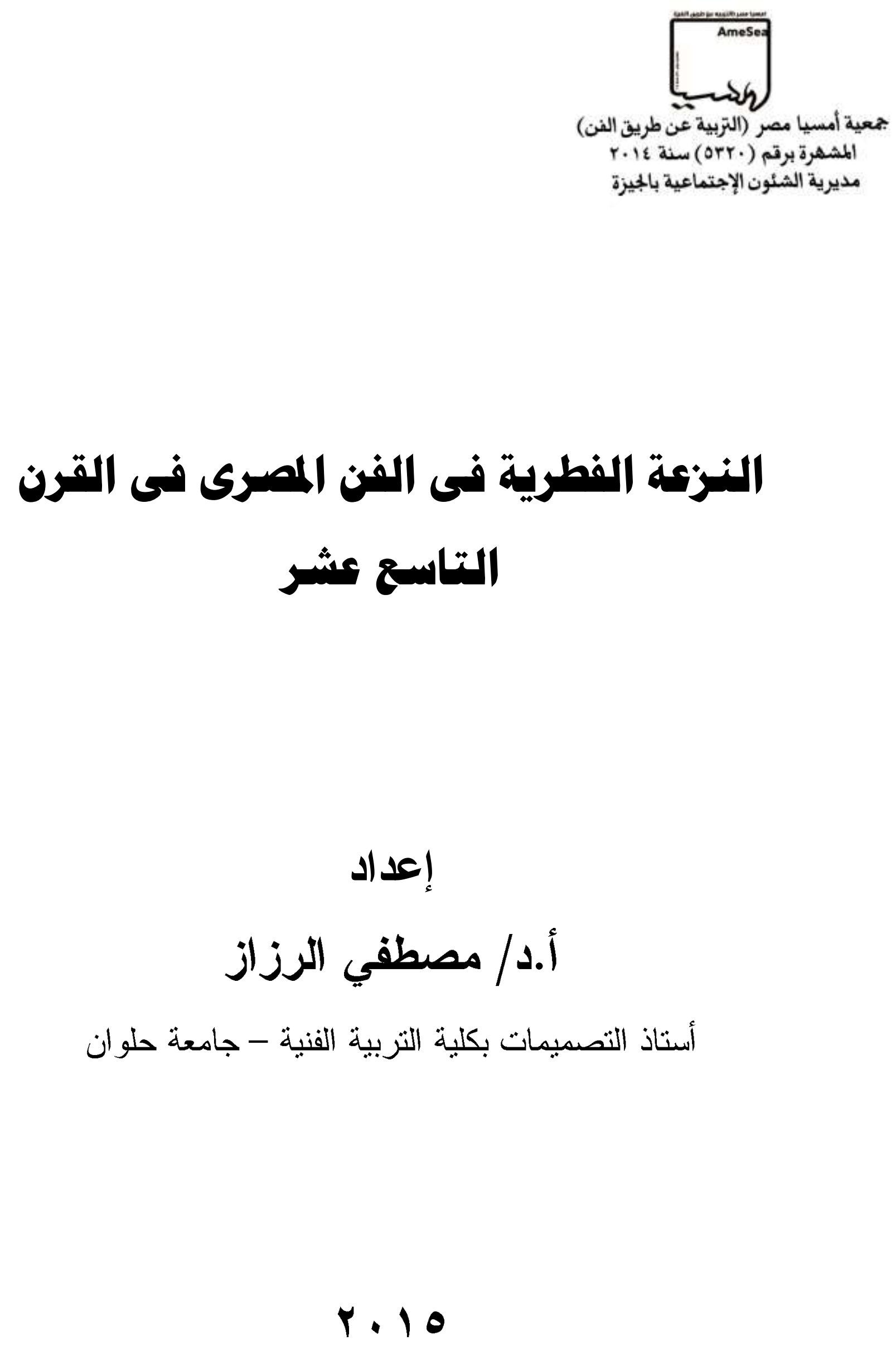




\section{النزعة الفطرية فى الفن المصرى فى القرن التاسع عشر}

تقدم هذه الدراسة تفسير ا ينشر لأول مرة عن أحوال فن الرسم والتصوير فى مصر فى تصى

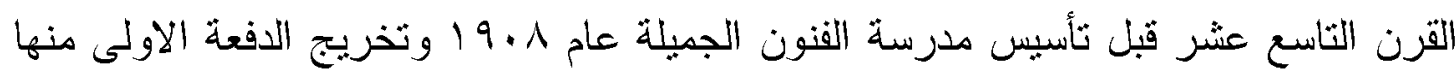

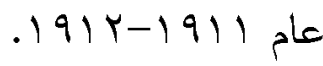

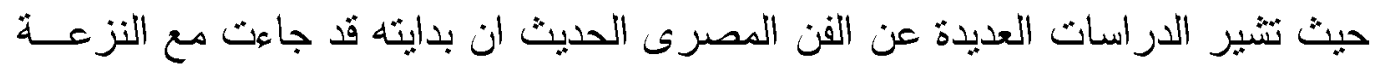

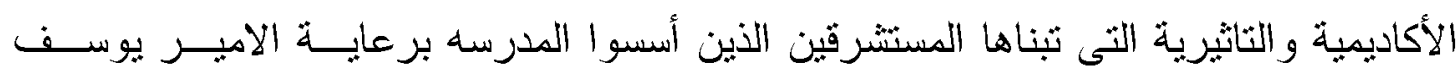
كمال. ولكن هذه الدر اسة نطرح أمثلة وأسماء وعناوين مر اسم ومحترفات فنانين مصورين مصريين

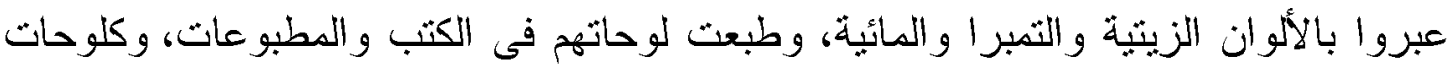

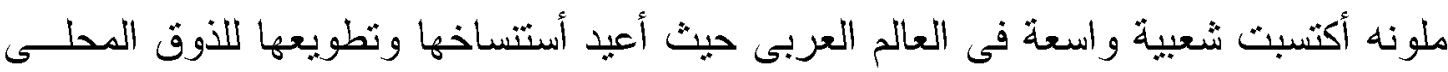

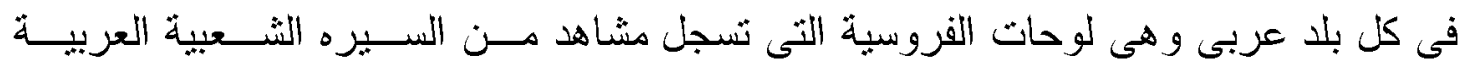

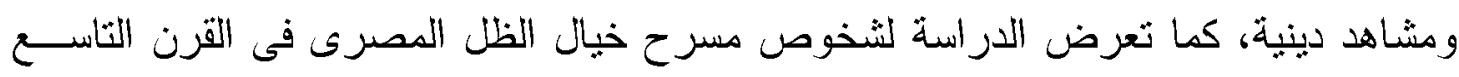
عشر ولنماذج من الايقونات القبطية.

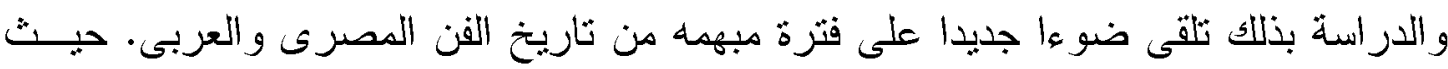

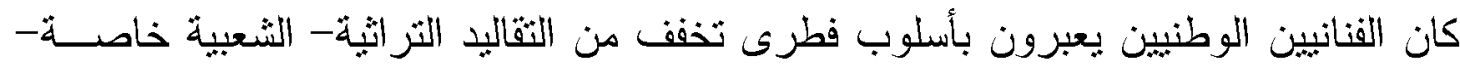

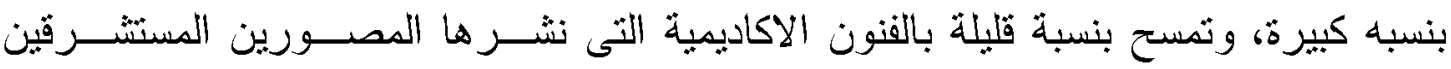

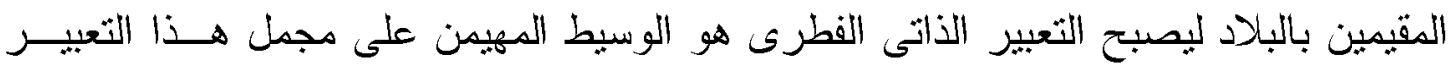

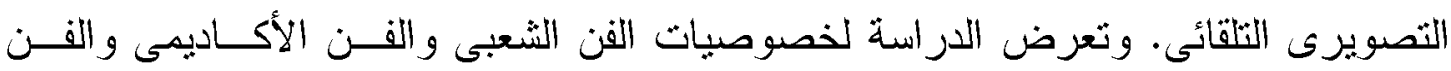

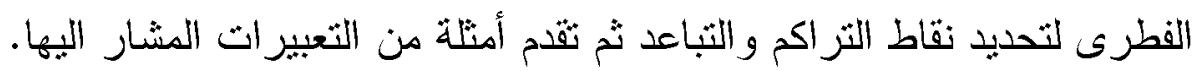

\section{الفن المصري قبل مدرسة الفنون الجمبية:}

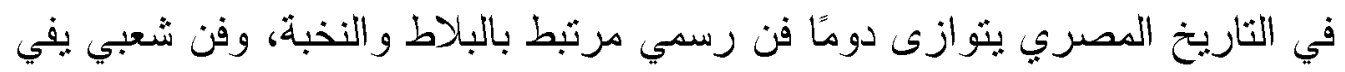

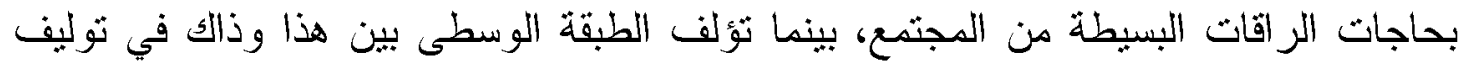

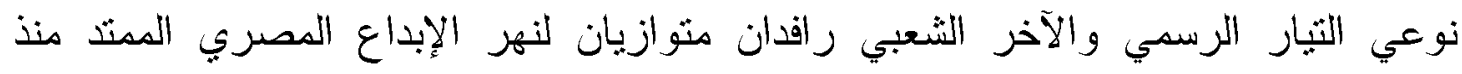

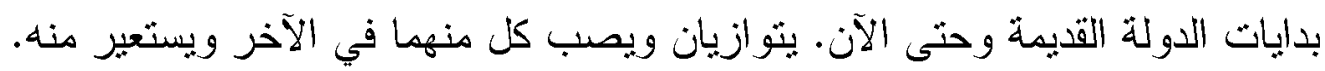

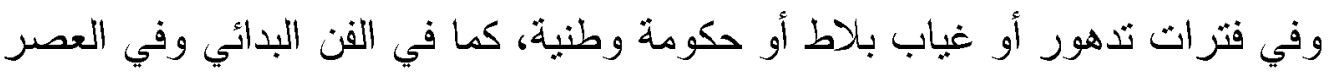
القبطي وفي المرحلة الأخيرة من الحكم العثماني على سبيل المثال، فإن الفن الرسمي ينسحب 
ويحل محله الفن الثُعبي لسد الفراغ، ليحفظ بعض من قيم الفن الرسمي في غيابه فيضُن بعضا من جمالياته و تقنتياته وقيمه هنتجاته الثعبية.

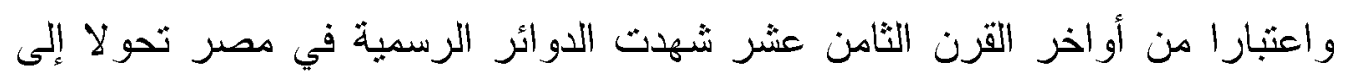

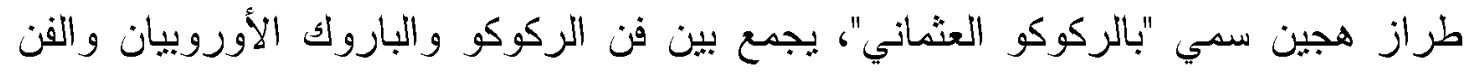

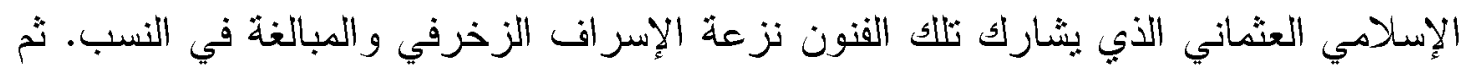

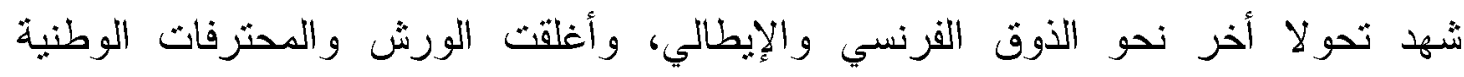

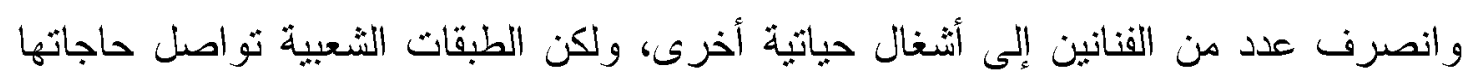
من الأعمال الفنية ذات المذاق المثصل بجذور الثراث، حيث ثميل الطبقات المثوسطة إلى الى الحصول على فنون تقربهر من ذوق الخاصة مع بقاء التقاليد المتو ارثة في تركيبة ما.

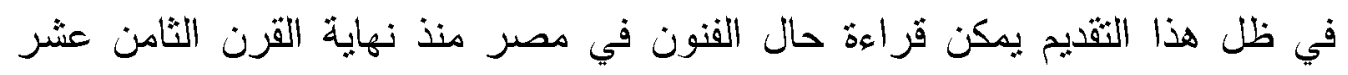

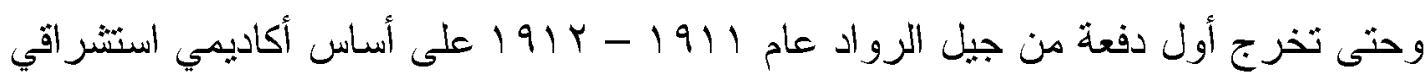

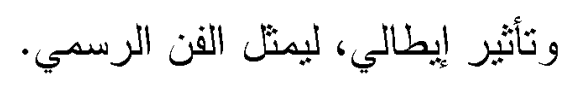

\section{طريق ثلاثي الاتجاهات:-}

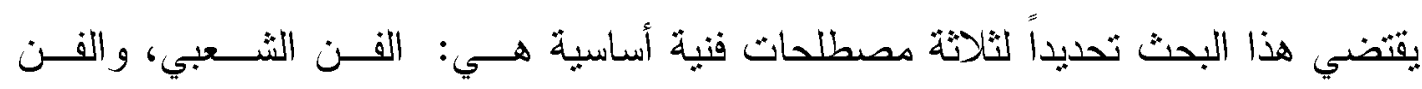

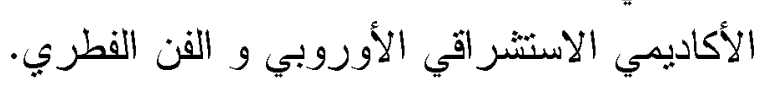

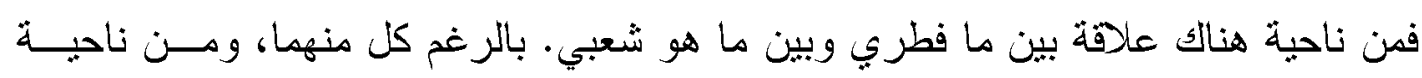

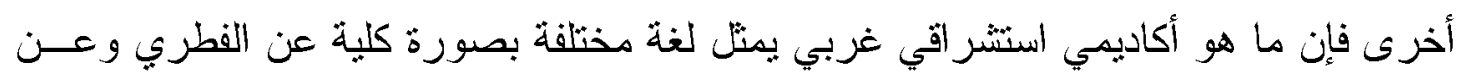
المصرب الثُبي و العربي بل وفي العالم كله.

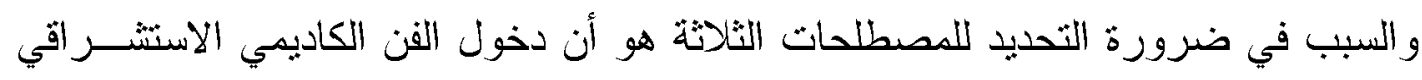

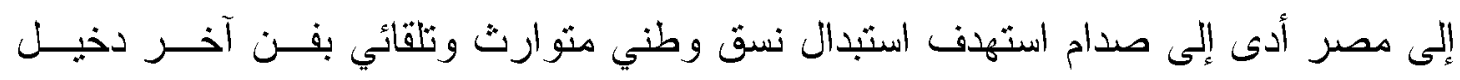

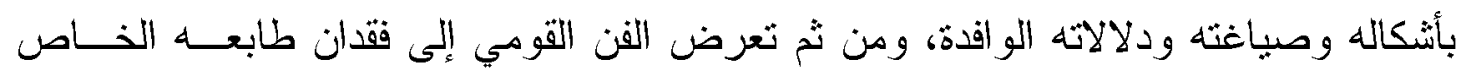
المستساغ في مجثمعه. وفي ذلك يشير سعد الخادم إلى ان الاساليب الفنية تثتبه المعادلات الرياضية التـي تــــنكن

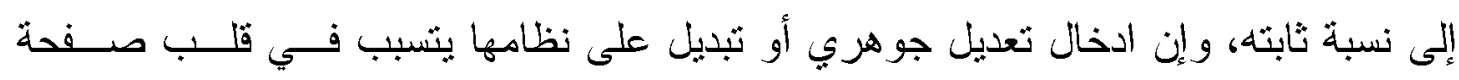

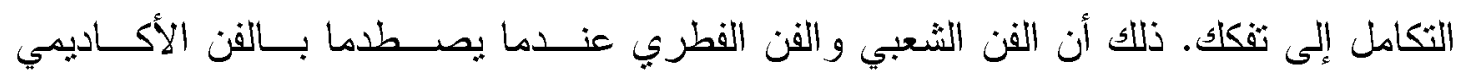

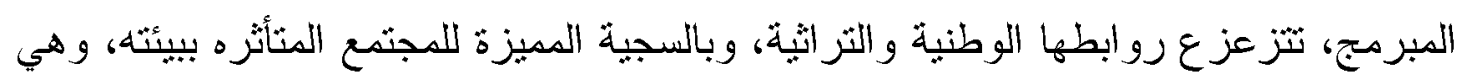
مصادر تغذيته وعوامل اسمثراره. وفيما يلي عرض للمصطلحات الثلاثة السابقة الإشارة إليها:

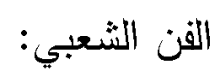
القن الاكاديمي الاستشر اقي:

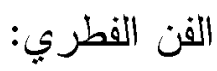




\section{الفن الأكادبيمي:-}

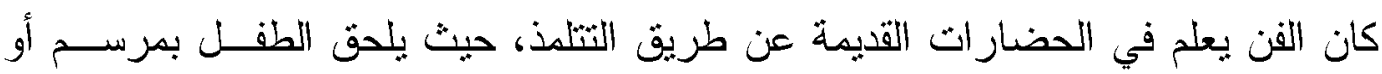

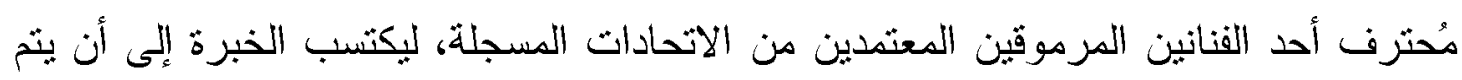
تكو ينه فيتحول إلى فنان مستقل وعضو في الاتحاد.

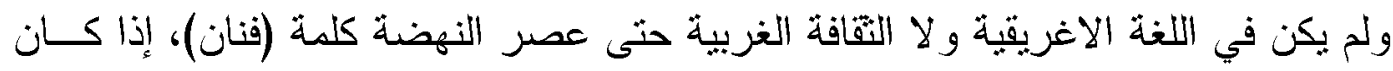
الفنان بمثابة حرفي متخصص في انتاج أعمال وفقاً لتكليفات ومو اصفات محددة مسن خـنـلاتل

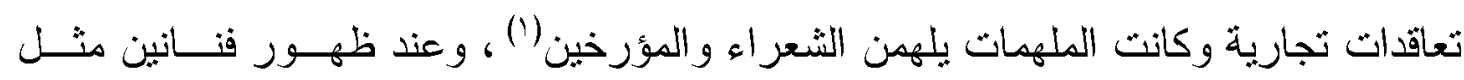

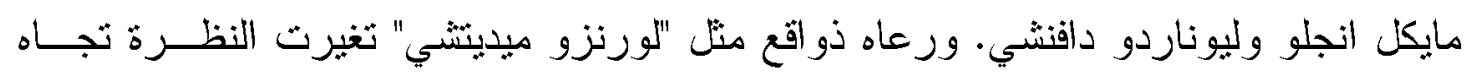
الفنان ومن ثم صار الاتجاه إلى انثاء أكاديميات لتعليم الفنون.

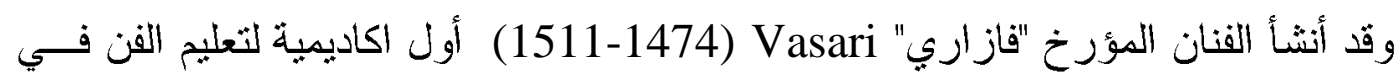

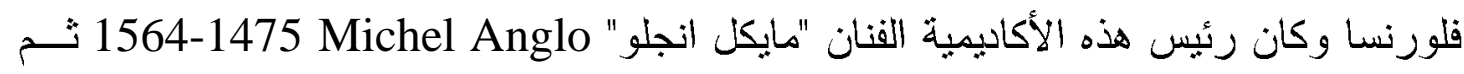

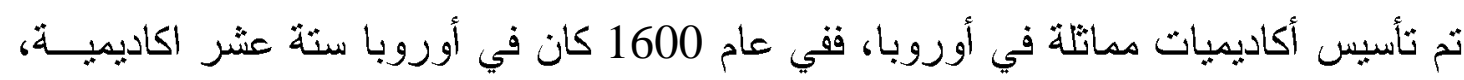

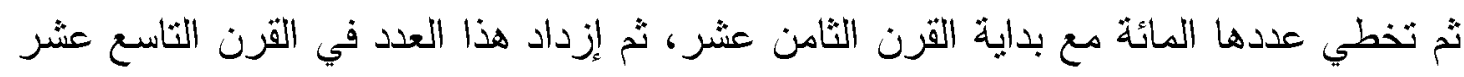

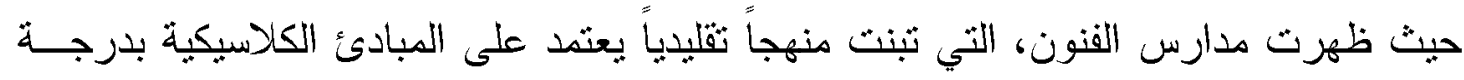

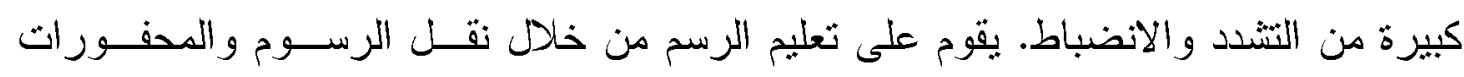

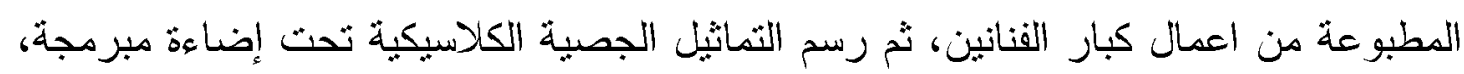

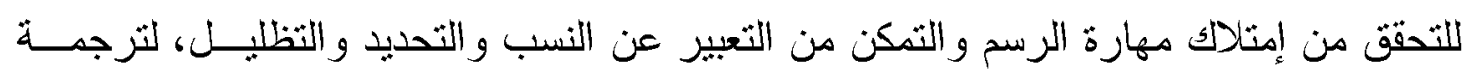

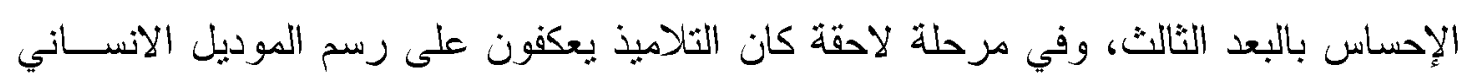

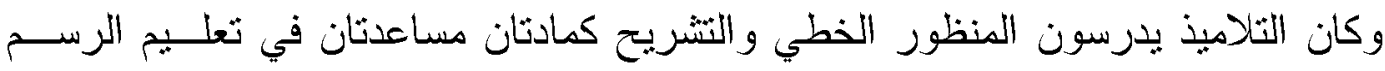

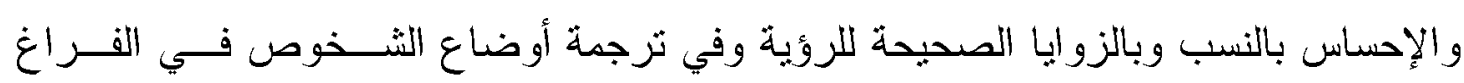
المحيط بها بصورة مقنعة. وكان التلاميذ يرسمون الجسد كاملاً ثم ينتقلون إلى دراسات تفصيلية للأيــدي والأرجـل و الرؤوس، وكان التلاميذ ينتقلون من مستوى دراسي دراسي إلى آخر وفقاً لتقافتهم في الرسم

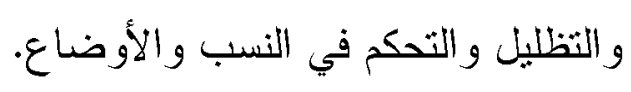

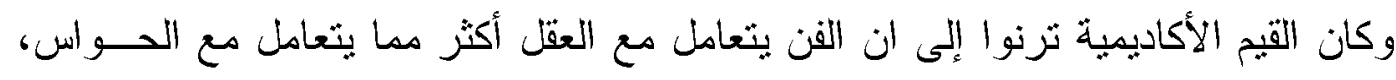

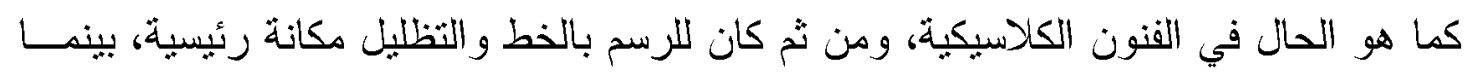
كان دور التلوين مجرد مكل ومساند للرسم.

1 - Boardman John: Greek Art, Thames and Hudson, London, 1996. 
وكان الأساتذة يشجعون التلاميذ على الرسوم السريعة من الواقع الحي لتتمية القدرة على الرؤية الشخصية وقدرة الملاحظة. وقد بينت مدارس الفنون الجميلة في القرن التاسع عشر اعنماداً على نهـــ الأكاديميـات التي أستث في فرنسا منذ القرن السابع عشر تحث الرعاية الملكية، لتتيح لاعداد محدودة جداً

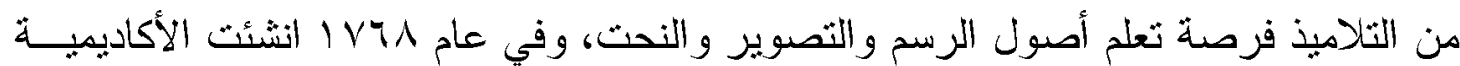
الملكية للفنون بلندن. أما في الثرق في أسيا، فقد كان ينظر إلى الفنان بإحتر ام باعتباره صاحب وسيلة نييله في النعبير وكان الأباطرة بمارسونها بفخر ، وكان للفنانين مكانة مرموقة و لأعمالهم الثقدير الثثين.

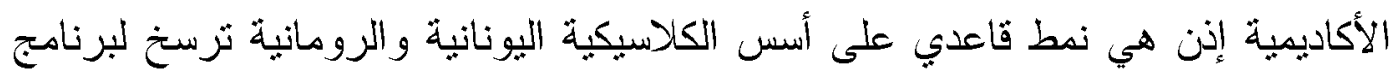
اتباعي صارم حيث لا مكان للانتيه و الفردية ولا للإبداع أو التمرد و التجديد.

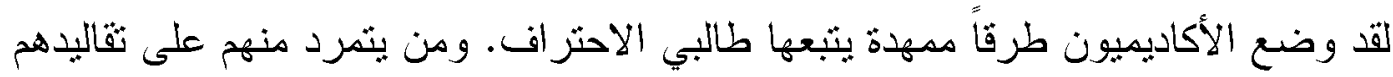
يصبح مطروداً منها. وقد أسست الأكاديميات لأغر اض تجارية وانتاجية لتلبــي حاجـات الرعــاه و الكنيســة

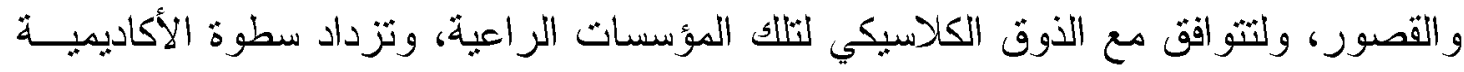

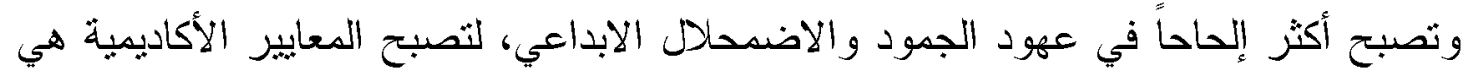

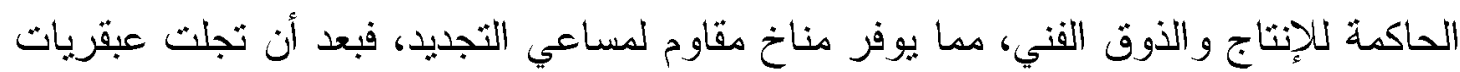

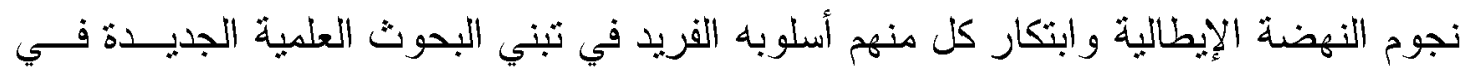

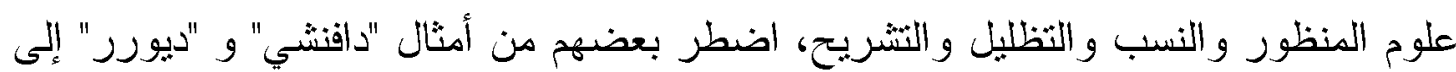

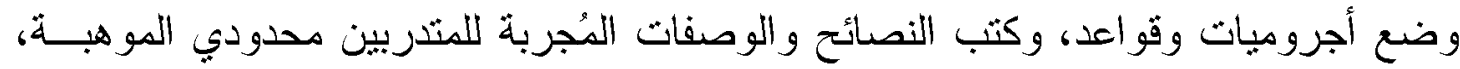
فوضعوا الرسوم النموذجية (الأمشق) الني تعين هؤلاء الحرفيين على رسم اللوحات الثقليدية،

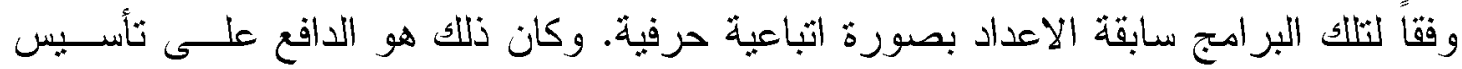

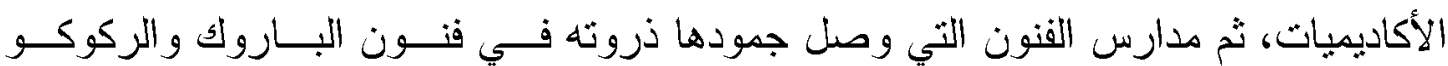
Baroque \& Roccoco الحرفية والبهرج الزخرفي على حساب النزعة الإنسانية الروحانية والنعبيرية.

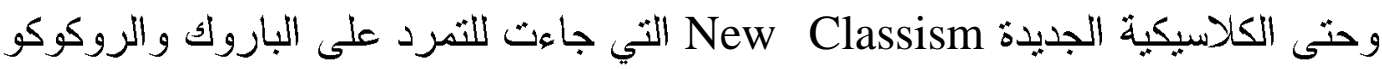
وان الرومانتيكية Romantisism التي استهدفت التمرد على الكلاسيكية الجديدة، فإن كلاهما تحول إلى هذهب قاعدي ومعايير أكاديمية صارمة.

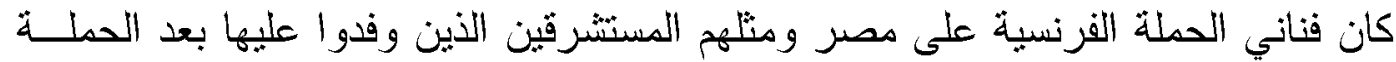

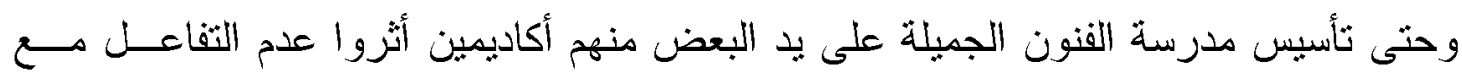


التيار ات المجددة في أوروبا ومن ثم دفعوا بالمدرسة إلى المنهج الأكــاديمي الأوروبــي منــذ

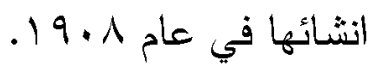

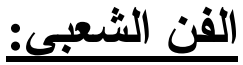

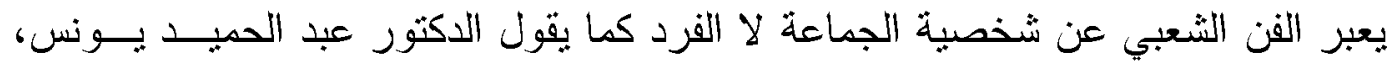

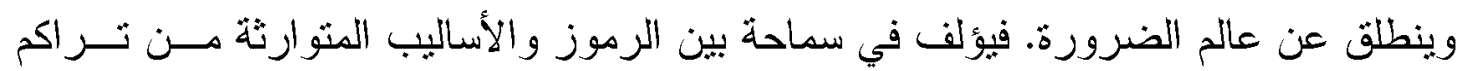

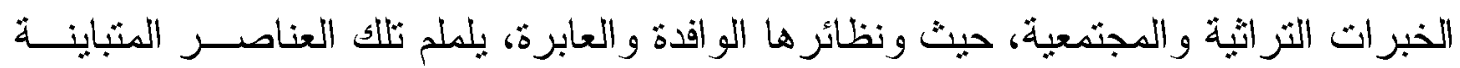

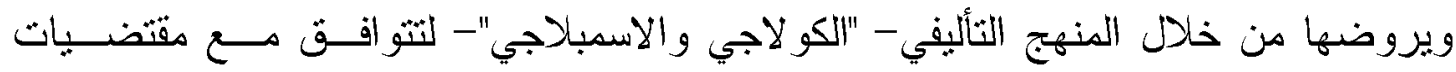

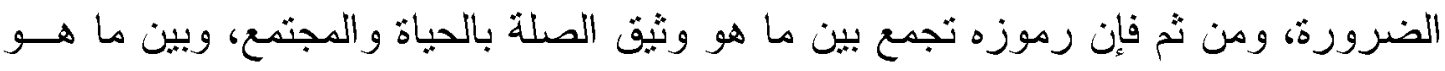
تاريخي و اسطوري.

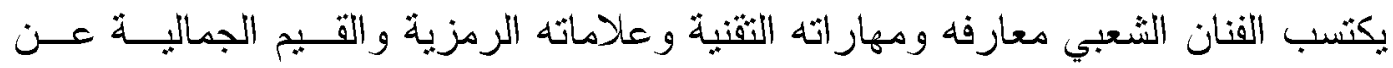

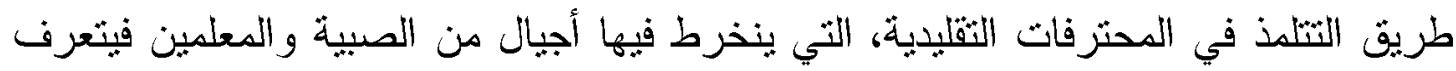

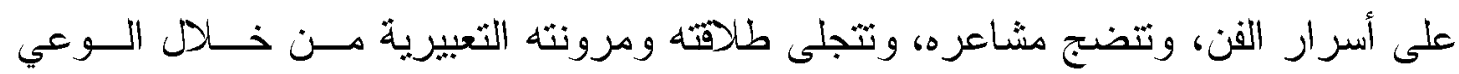

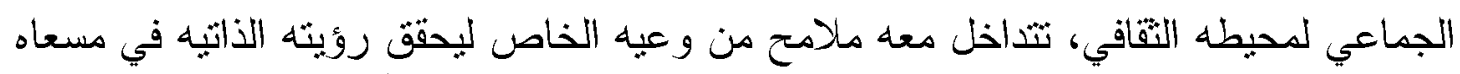

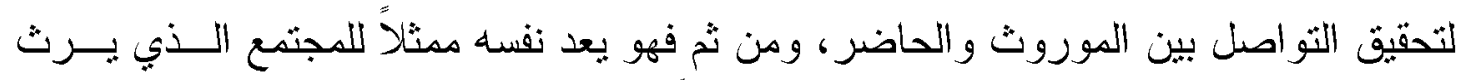

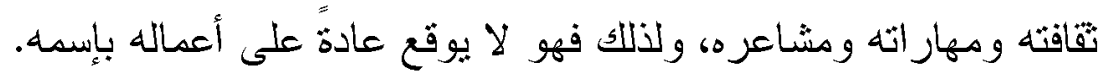

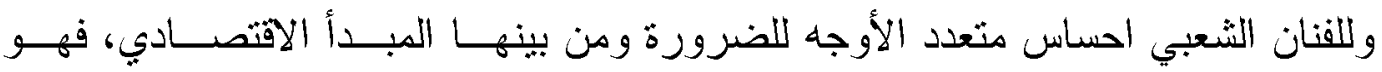

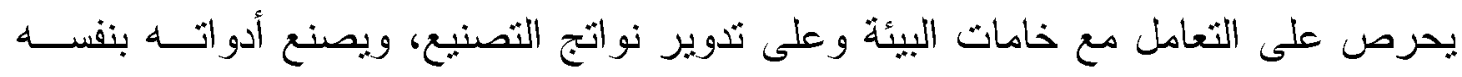

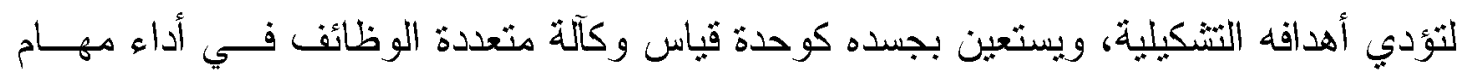

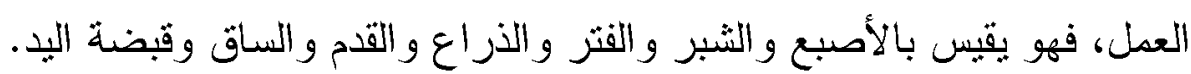

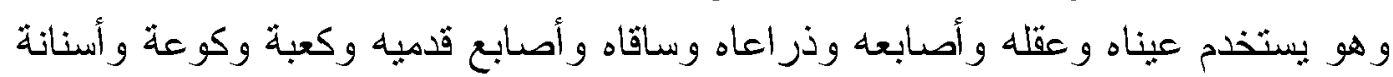

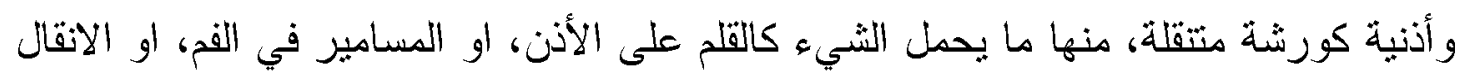

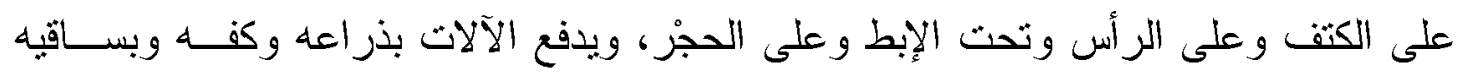
و أقدامه، ويثحكم على أجز اء أخرى بأصبع يديه وقائ وقدميه.

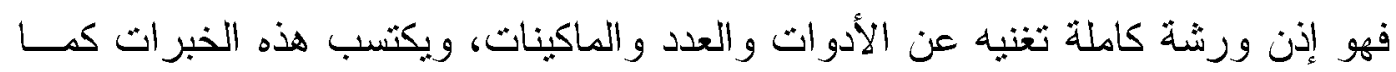

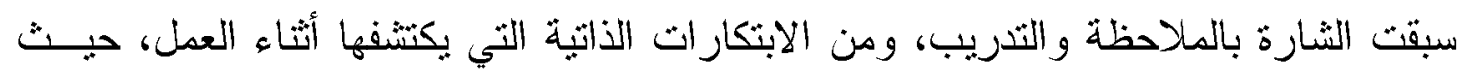
تظهز ملامح ابتكاره وتميزه النخصي بين أقرانها

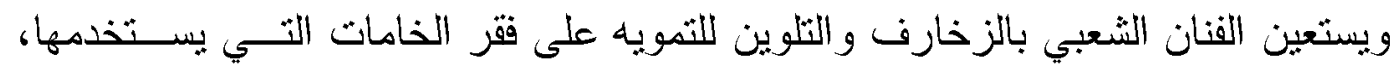

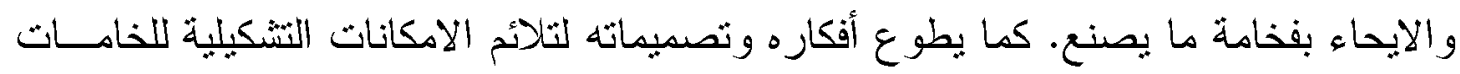


بينما يكون الفن الشعبي من ناحية، والفن الكاديمي من ناحية أخرى وبالرغم مـن تباعـدهما

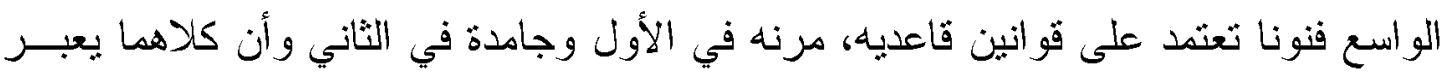

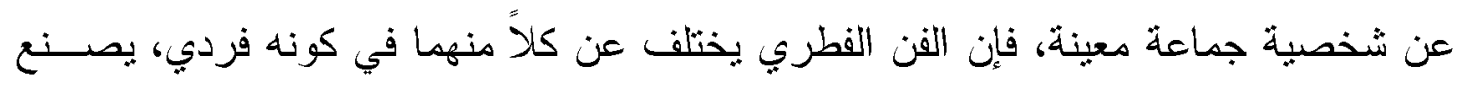

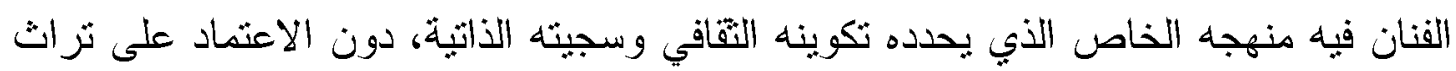

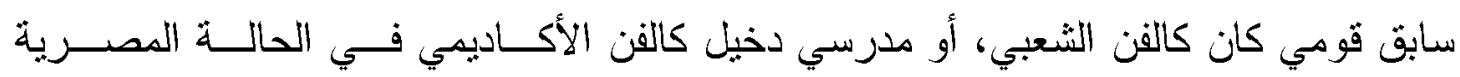
و العربية وفي الثرق عموماً.

وبينما يتطلب ممارسته فنوناً أخرى كالموسيقا والكتابة المسرحية وصناعة الأفلام تــو افر

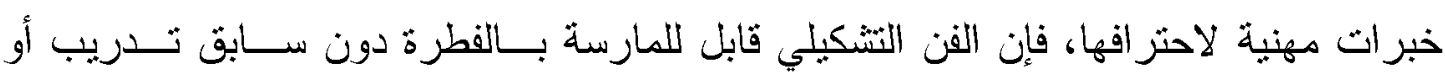

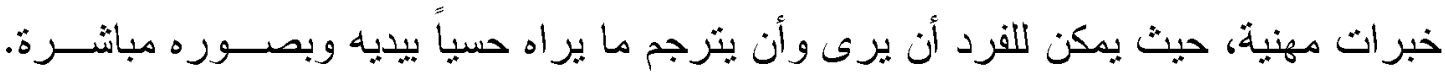

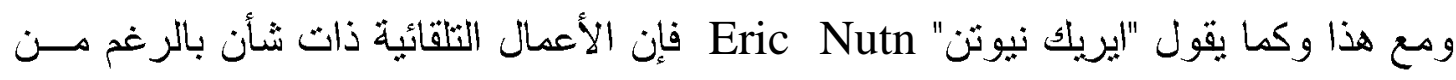
السذاجة البادية في شكانها. ويقول "ديفيد لاركن" Daivid Larkin أن الفن الفطري ليس له ماضي و لا كستقبل، لأنه

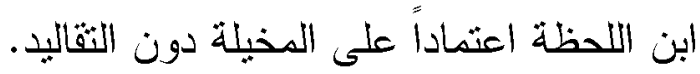

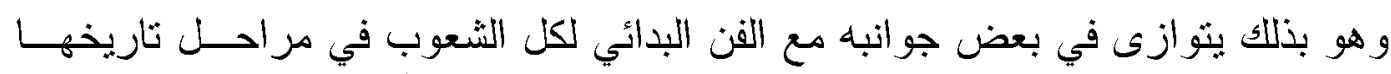

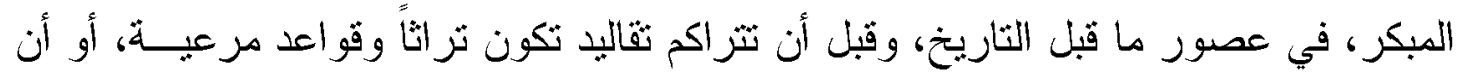

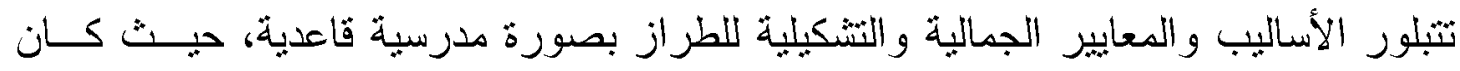

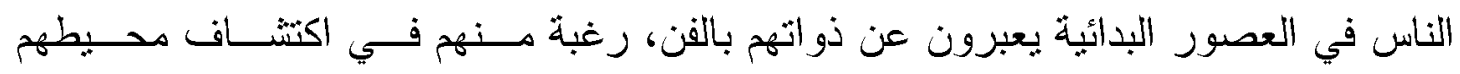
الغامض وللنظلب عن مخاوفهر والتعبير عن افراحهر.

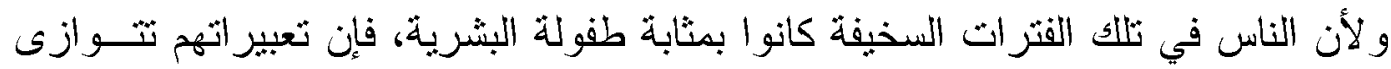

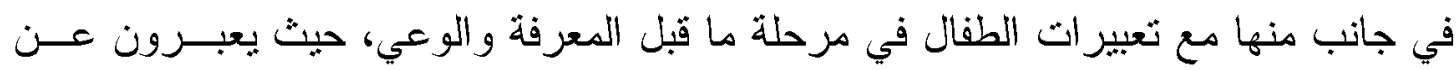

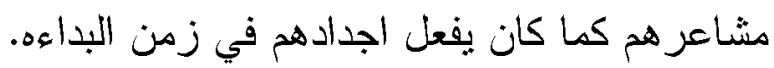

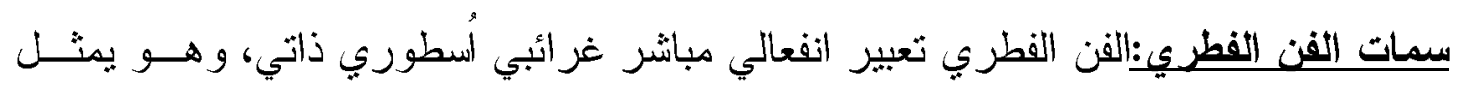

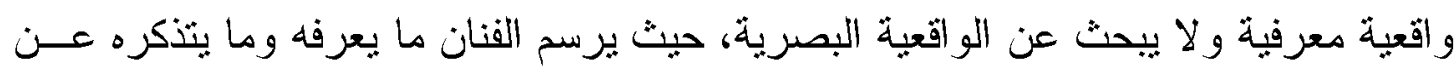

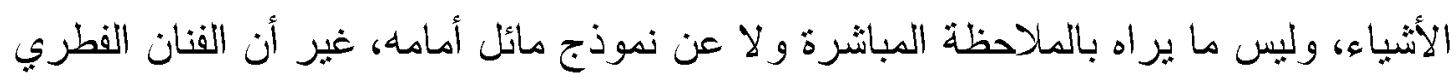

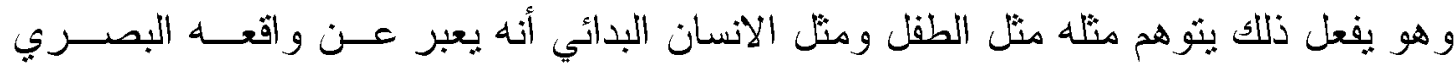

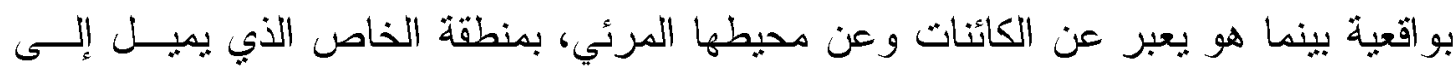

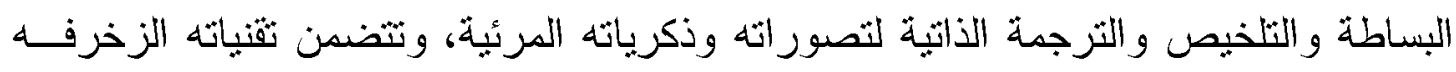

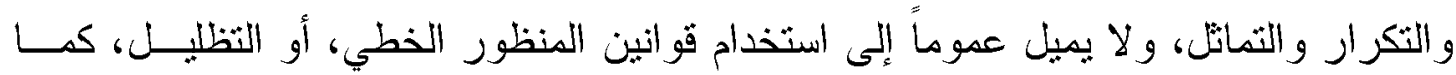

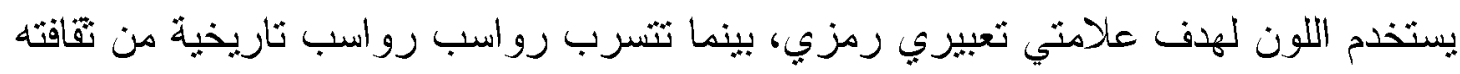

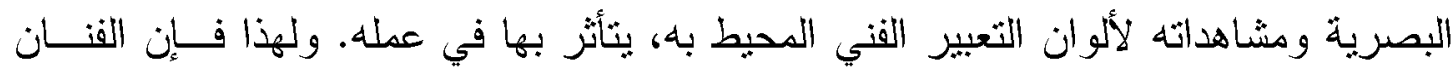




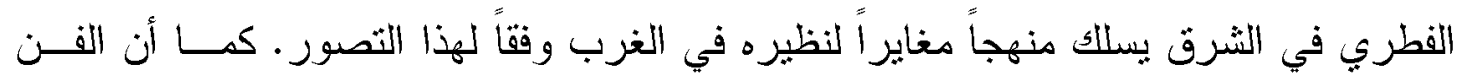

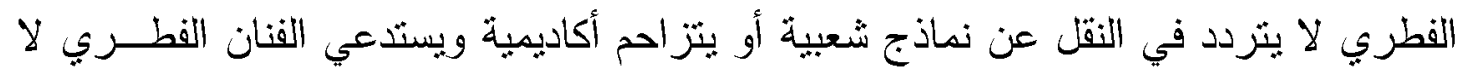

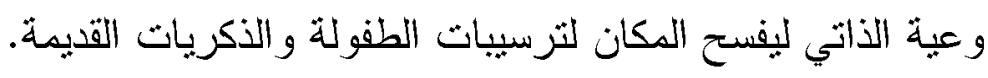

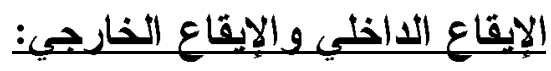

الايقاع واحد من الأسس الجوهرية لأي فن، وهو الأبي يفصل بين ما هو فن وبين ما هو

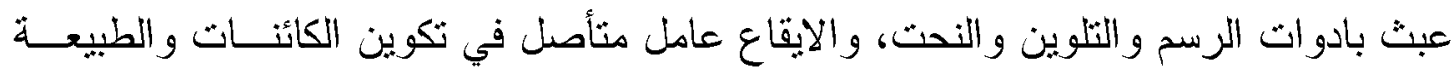

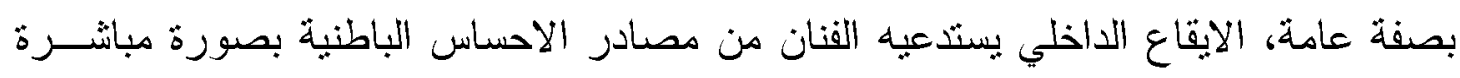

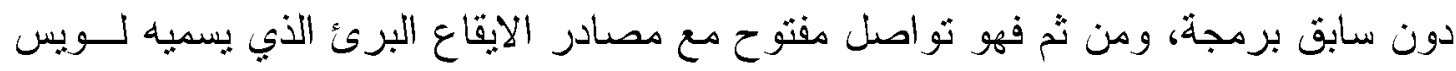

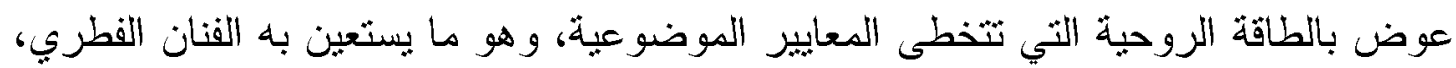

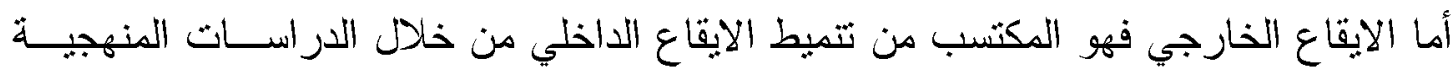

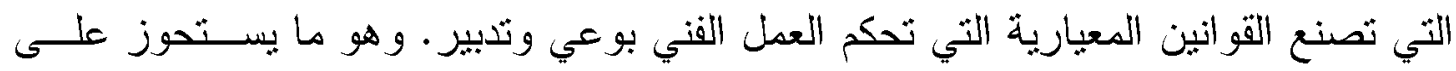
وجدان الفنان الأكاديمي.

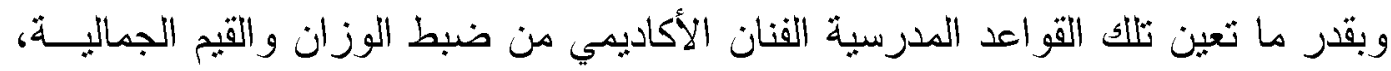

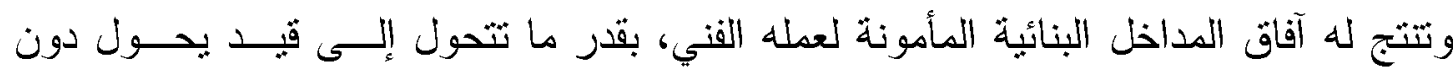
انسياب حسه وسجينه الخاصة. ويشترك الفن الفطرى مع الفن الشعبى خاصة وفنون التراث بصفة عامة فى ســـات التهات

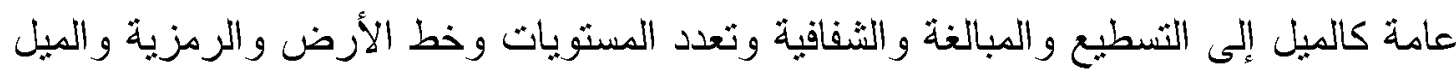
إلى الزخرفة.

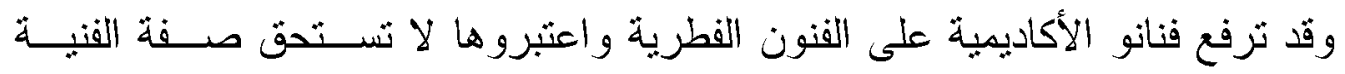

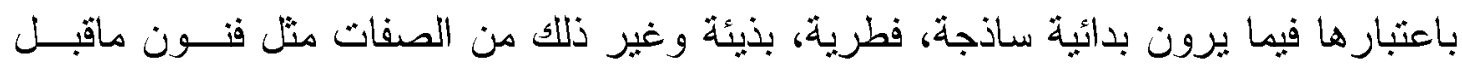

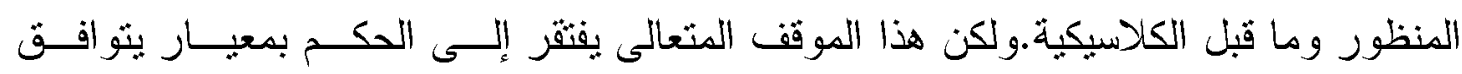

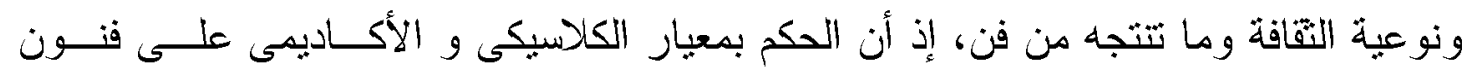
أخرى بعكس تعالى غير مبرر وضيق أفق.

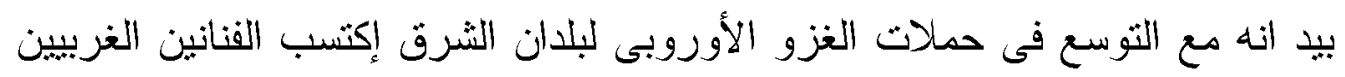
خبرات ورموز ومشاعر جديدة لتجديد فنونهم الجامدة.

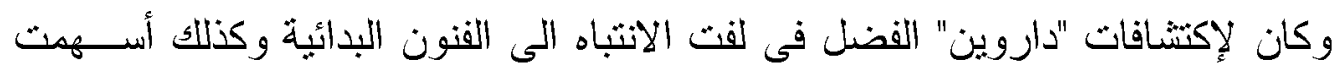

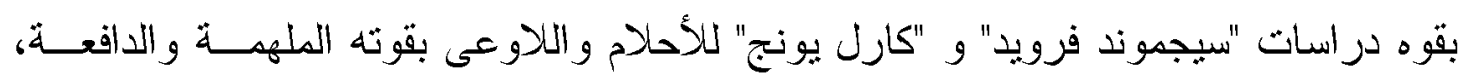
ودراسات "الأثثروبولوجيون" الأو ائل فى تحرير النمطية الأكاديمية، والإلتفات إلى أهية الذية الذاتية

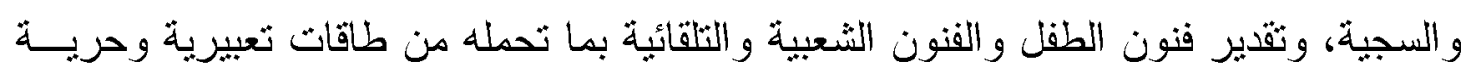


و اذداد الإهنمام بالمتاحف "الأثتوغر افية" و الثعبية و البدائية فى أوروبا، وكـذللك تجارة المائور ات الغرائبية من أفريقيا و آسبا، التى لفتت نظر طلبعة الفنانين إلى الجوانب

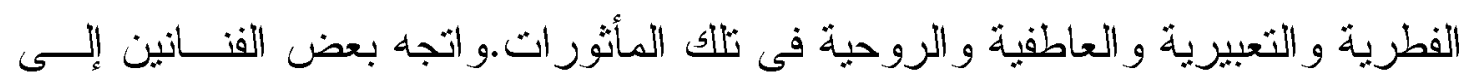

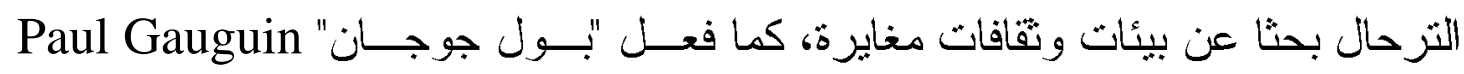
1848-1903 حين سافر إلى جزر المحبط الهادى بالقرب من الفلبين بنظر إلى الفــن "البولينيزى" ويعيش حباة البسطاء. ولجو ء بيكاسـو

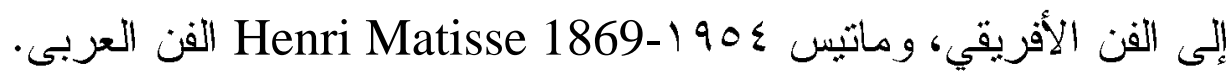
كان الفنانيين بذلك يسعون إلى قطيعة مع جذور الفن الغربى الكلاسيكية بحثـ عـن فئن

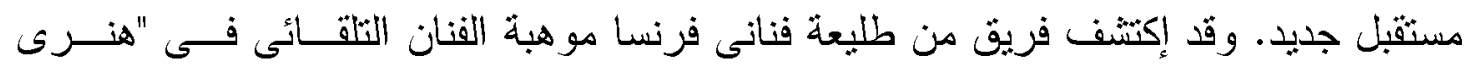
روسو" 1910-Henri Rousseau و وقدموه إلى الوسائط التقافية بتقدير ات كبيرة.

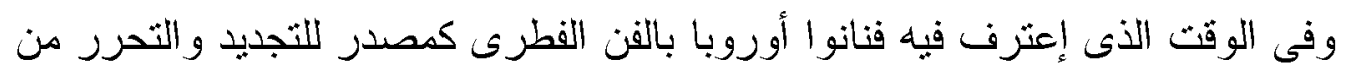

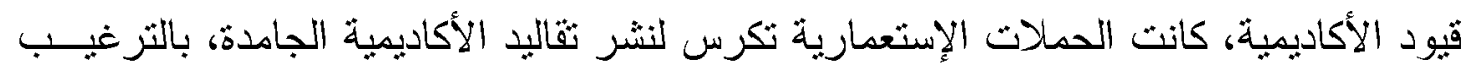

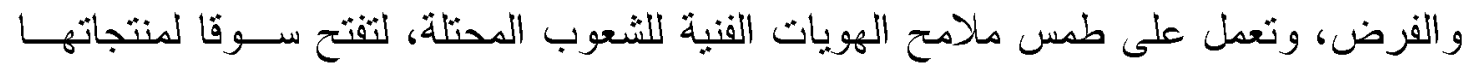

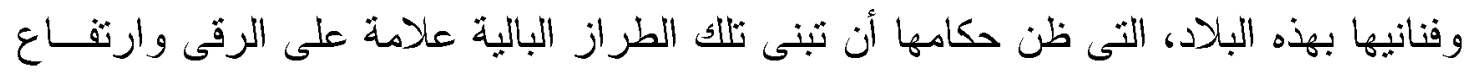

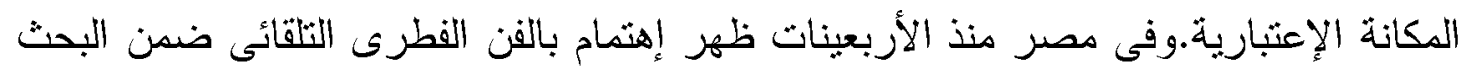

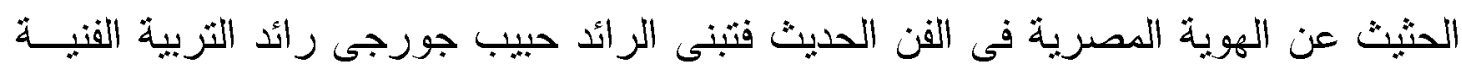

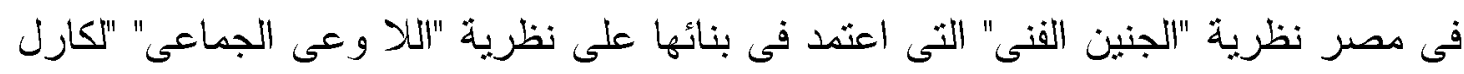

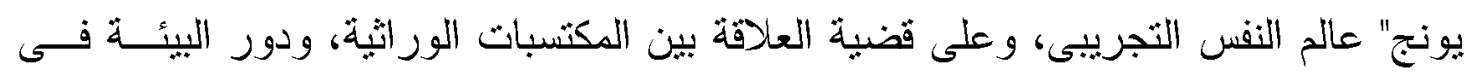
تنشيطها أو إحباطها.

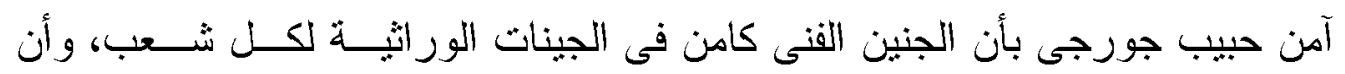

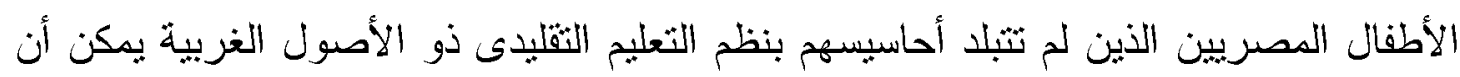

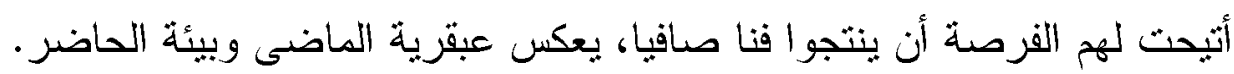

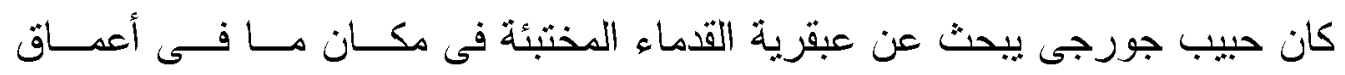
الأطفال، خاصة مرحلة ما قبل فنون الأسر الفرعونية.

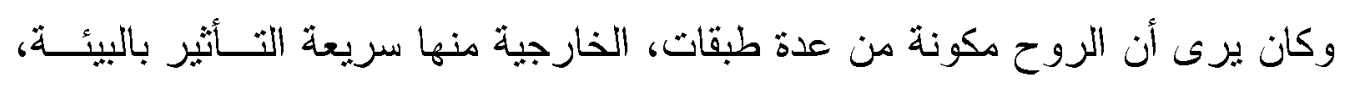

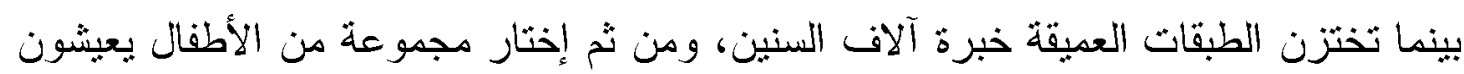
على الفطرة ذاتها التى عاشها أجدادهم.

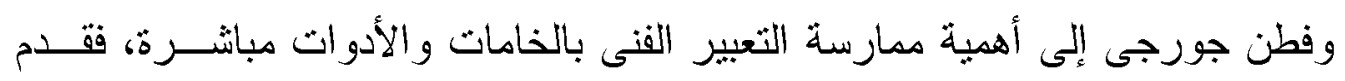
للأطفال تجربته الطين الأسو انى وخيوط الصوف اهبة بدلا من الرسم والتلوين. 
الفنان الفطرى لا يرى نفسه فطريا، ولكنه خاصة إن لاقى در مناسب من الثقدير الفنى

والإجتماعى يرى نفسه كفنان و اقعى ماهر يتمتع بما يتطلبة ذلك من مهارة.

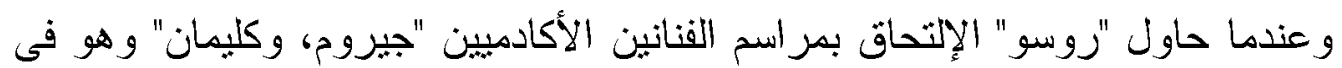

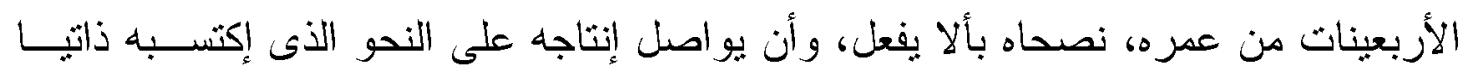
بالفطرة، وقد رأى فيما بعد مؤرخ الفن جومبرش E.H.Gombrich صواب النصيحة، معتبرا

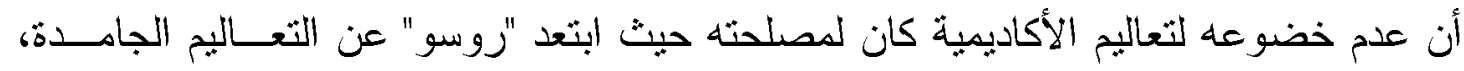
وعن النظريات الفكريةالمرتبطة بها، مما مكنه من الحفاظ على سجيته وطلاقته البريئة.

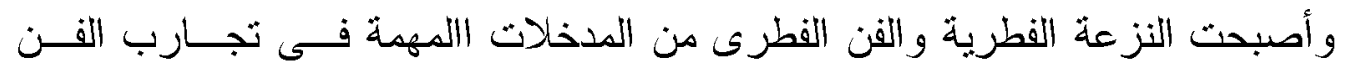

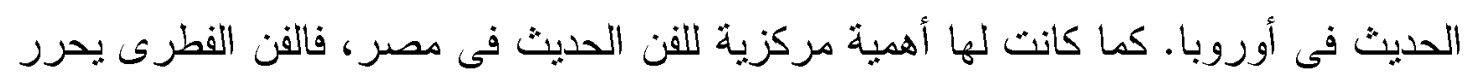

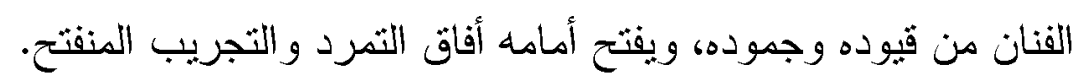

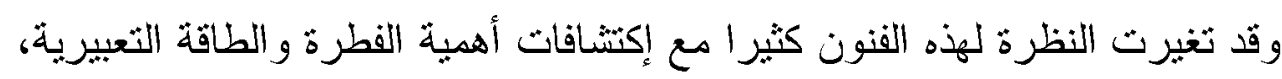

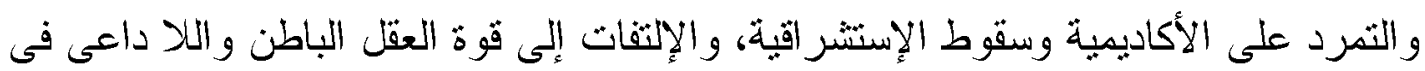
تحريك البعد الأبداعى من خلال سجية الفنان، و ألقى الضوء ولهية على عدد من الفنانين التلقائيين

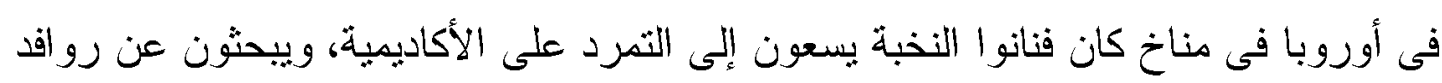

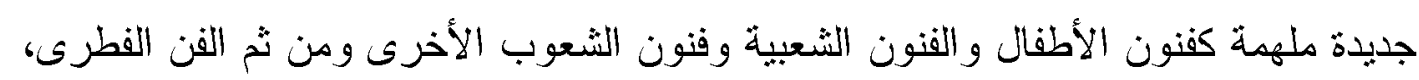

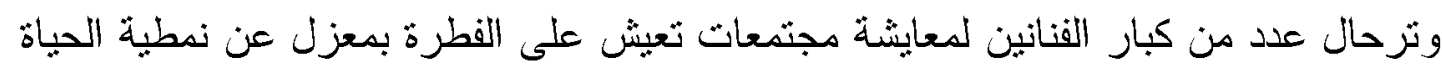

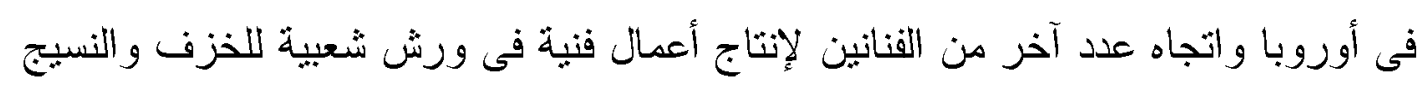
مثل الفنانيين: بيكاسو - وميرو - وشاجال - وليجيه.

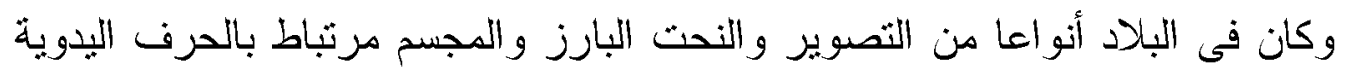
كمنتجات النسيج و الكلية و الخيامية و انشغال الخزت ولت والمعادن و الخشب و غير ها من الخامات.

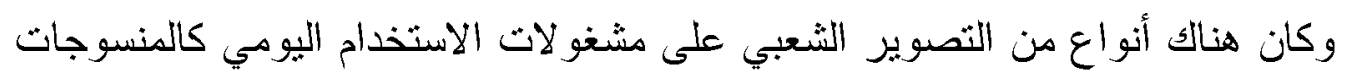

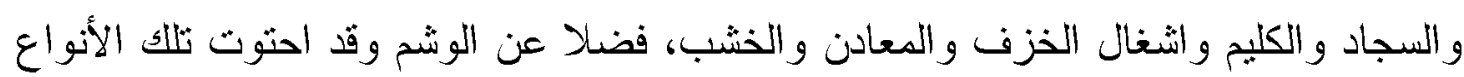
على رسوم ورموز مصورة وتكونيات بعضها زخرفي وبعضها الأخر نعبيري.

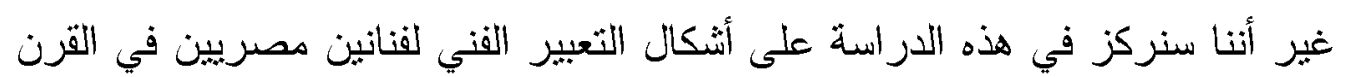

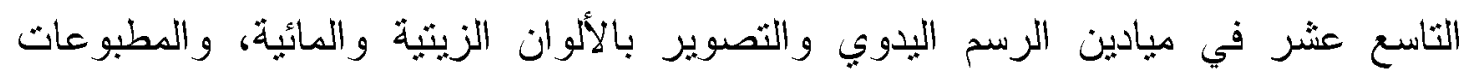
الليثو غرافية الملونة والرسوم التوضيحية للكتب المطبوعة بتقنية الطباعة البارزة (الثيبو)

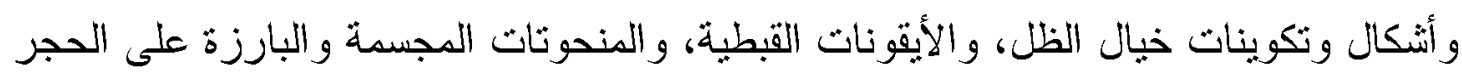
والخشب المستخدمة لأغر اض زخرفية أو رمزية أو نعييرية. 


\section{المصورين رسامي الثبد:}

تندر الوثائق التي تشير إلى وجود رسامين ومصورين وطنيين في دصر في القرنين

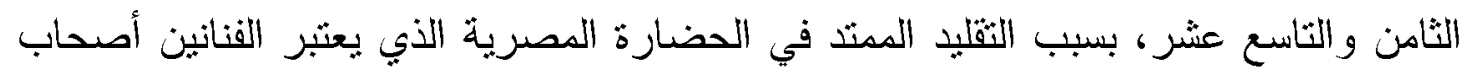
حرفة إنتاجية، وكان الفنانون ينظرون إلى أنفسه بنفس النظرة ومن ثم فيندر أن يوقع الفنان

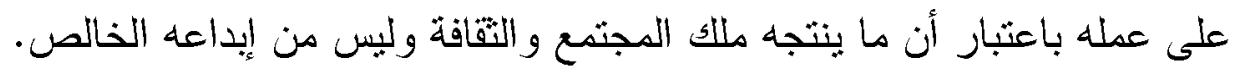

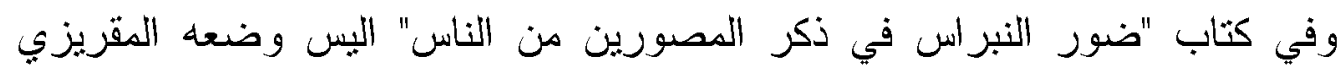
وعرفنا عنه رغم صناعه من مصنفات معاصريه، فضلا عن العلاقة محمود بتمو في مصنفه ونه

$$
\text { الهام (التصوير عند العرب). }
$$

وقد أولى سعد الخادم اهتمامًا فريدا بدراسة حالة فن التصوير المصري في القرنين

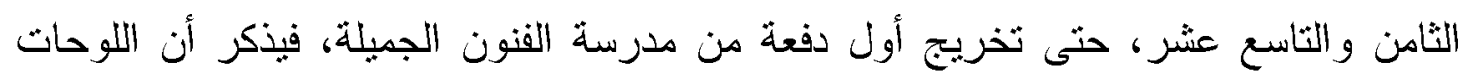
الفنية المرسومة بواسطة رسامين مصريين كانت تتزين قصور المماليك والأعيان وكبار

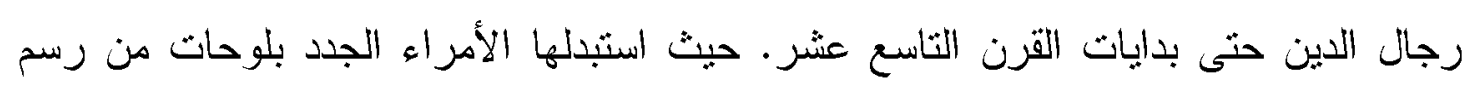

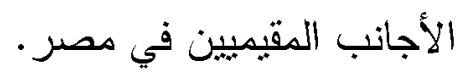

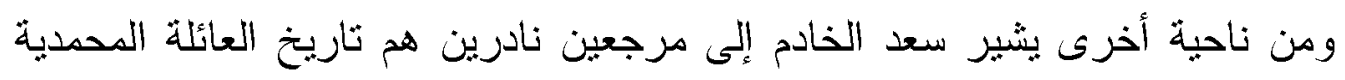

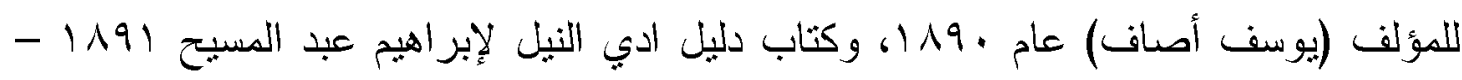

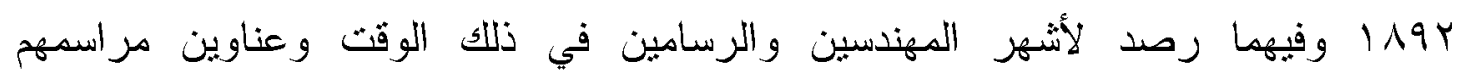
ومحترفاتهخ وهم

$$
\begin{aligned}
& \text { إبر اهيم سالم، ورزق يحيى بســـوق الزلط }
\end{aligned}
$$

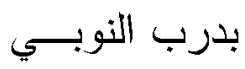

$$
\begin{aligned}
& \text { بيومي عبدالله } \\
& \text { بدرب المـلاح } \\
& \text { حسن أحمد البليدي عنداله } \\
& \text { باب لبار ع الطو ائي } \\
& \text { حسـن الصولي } \\
& \text { باب الثـــعرية } \\
& \text { حجاج يوســ } \\
& \text { بالأزبكيــة } \\
& \text { بدرب المــلاح } \\
& \text { عباس ســد } \\
& \text { بحسارة أبو بكر } \\
& \text { محمد حسـين }
\end{aligned}
$$

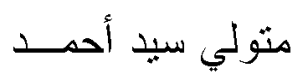

$$
\begin{aligned}
& \text { هـLل محدـد }
\end{aligned}
$$

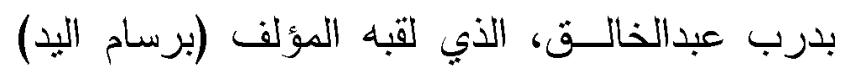

ومرسمه بجوار مرسم المستشرق ، "مانشيني" بشارع كلوت بك وأن "فورشيلا" الذي أصبح

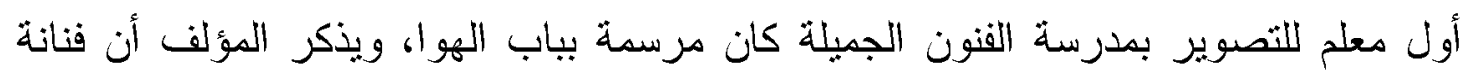


مصرية اسمها نظيمة سليم كانت ثرسم اللوحات بالألوان لتصوير موضوعات من البيئة

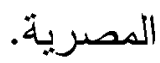

وفي كتاب لعالم المصريات الألماني "هينريش شافير" Heinrish Shafer عن نحليل

القيم البنائية في الفن المصري القيم، نشر في أول القرن العشرين رسما توضيحيًا خطيًا نادرًا

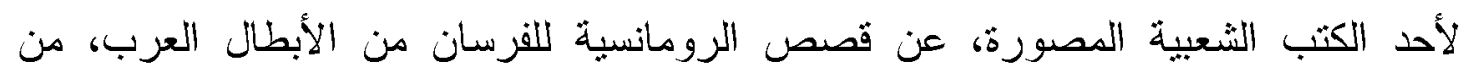
مطبوعات القاهرة في أواخر القرن التاسع عنر، يمثل الرسم سيدة تجلس على مقعد أمام

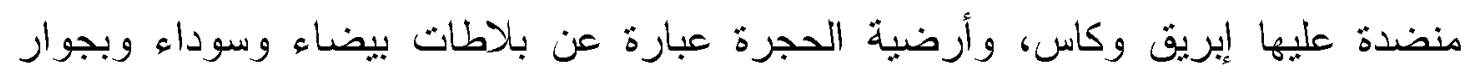

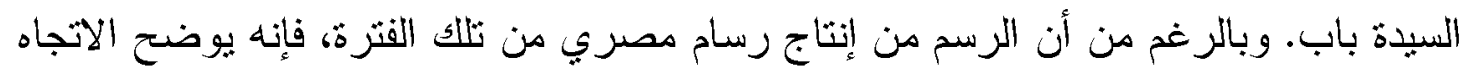

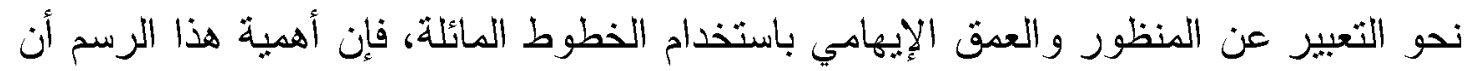

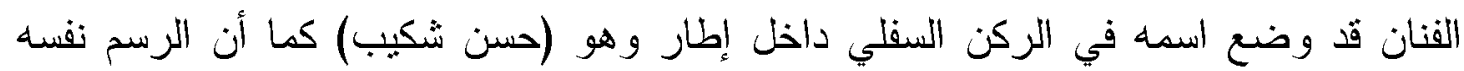

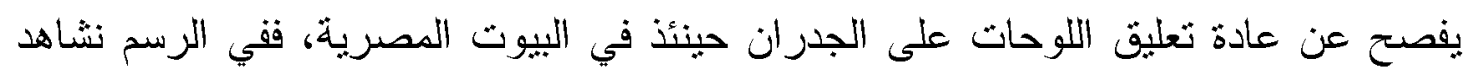
لوحة معلقة على الجدار.

وفي الثمانينيات من القرن الماضي شاهدت في مجموعة الأستاذ سعد الخادم لوحة

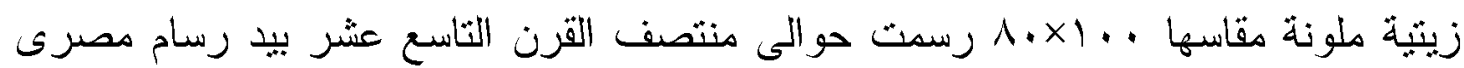

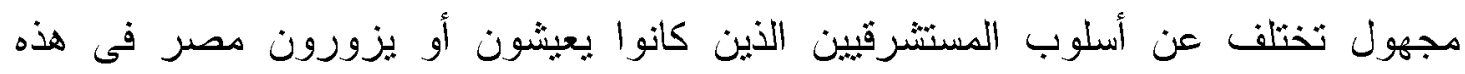

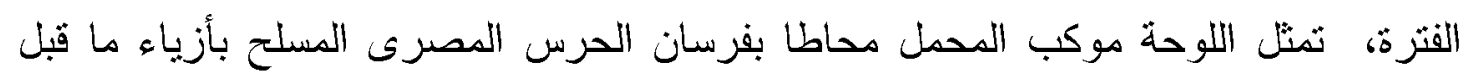

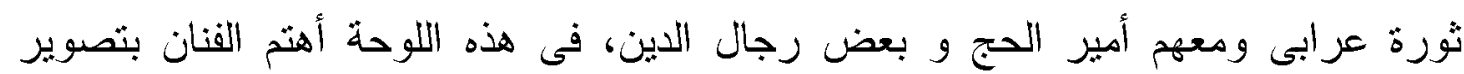

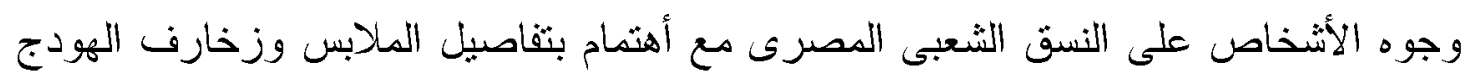

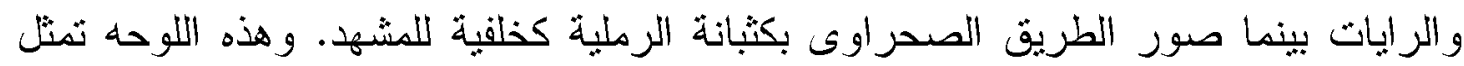

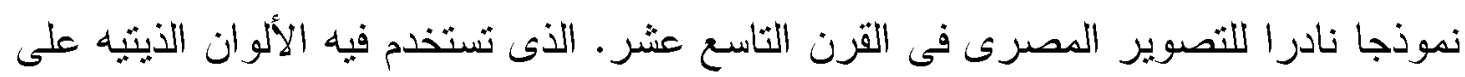

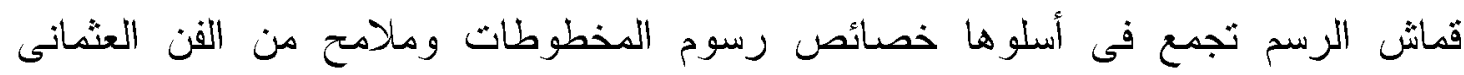
المخصب بإيحاءات أكاديمية و استشر اقية.

\section{الأوعية التعبيرية للرسم والتصوير: بائانية}

عبر الرسامين والمصورين المصريين في القرنين الثامن عشر والتاسع عشر بطريقة تختلف كثير ا عن الأساليب الأكاديمية والاستشر اقية والأوروبية التي ذاعت فين في البالاد.

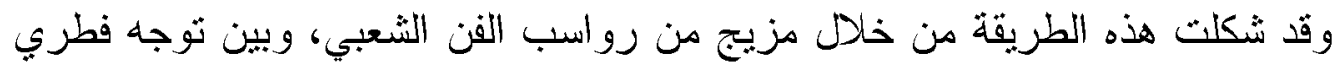

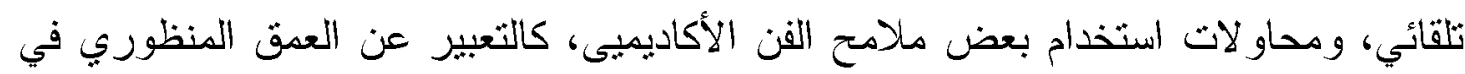
بعض الأحيان باستخدام خطوط مائلة وتصغير العناصر البعيدة عن القريبة، والتظليل 
ولذلك فإن فنون التصوير التي تواجدت في المجنمع المصري قبل نخرج الدفعة

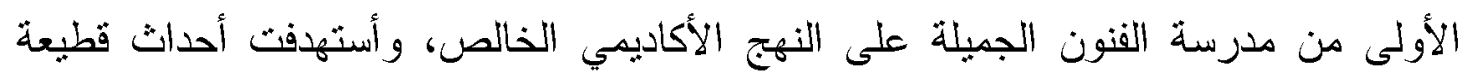
كاملة مع الثراث الفني السابق عليها في البلاد.

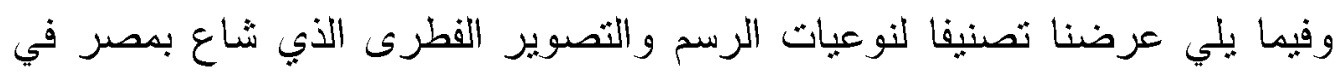
تلاك الفنرة، و الوسائط الثي نفذت بها و الأغر اض الثي عملت من أجلها.

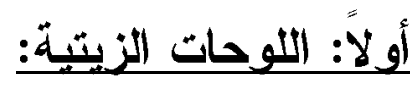

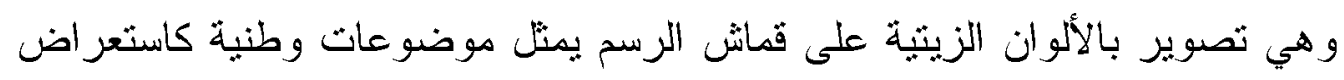

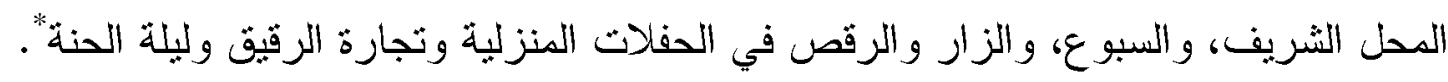

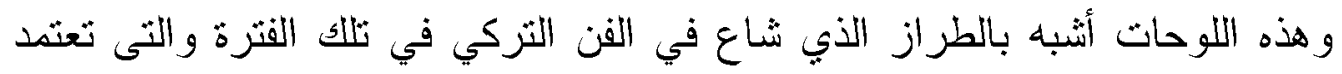

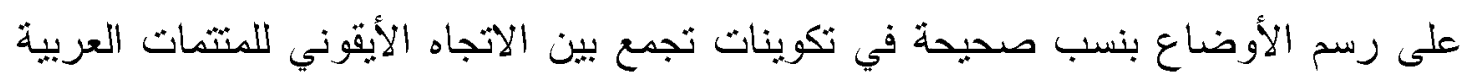

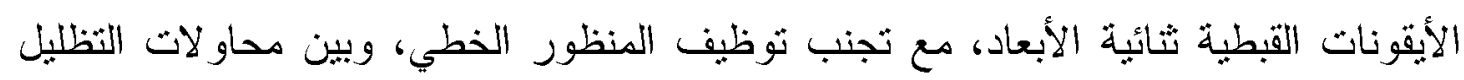

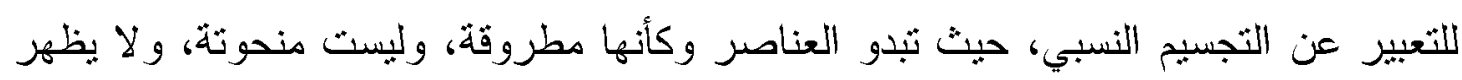
التعبير عن مستويات البعد الوهمي في عمق اللوحات، إذا تبدوا اللحوات وكأنها مشاهد

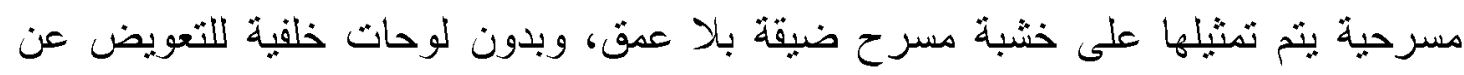
ذللك، وبالنظر إلى الصور الفونوغرافية التخت الموسيقى العربي في مصر في ثلاك الأونة يتضح أن هناك توازيا شديد التقارب بين تصفيف العازفين وبين هذه اللوحات.

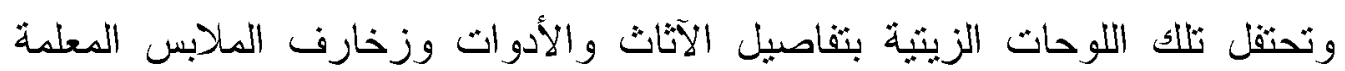

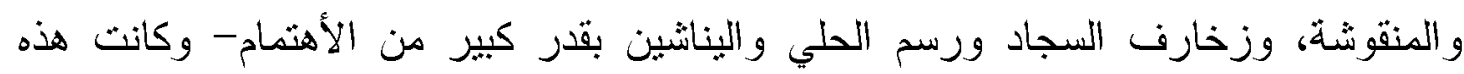

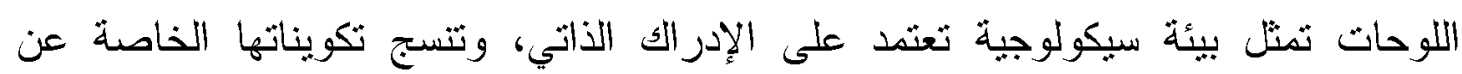
المرئيات من منظور ذانية الثقافة، حيث تنكون الصور الذهنية عن المرئيات من منظور ذاتئية

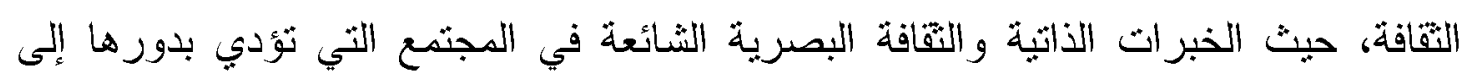
ثنات الإدراك للانشكال والألوان. بينما يؤول المستقبل الصوربإطفاء، لمعاني عليها لأنها

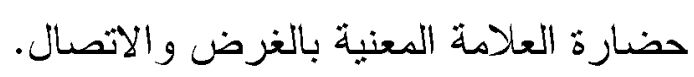

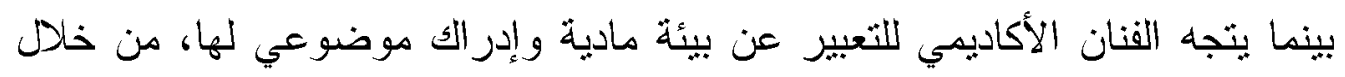

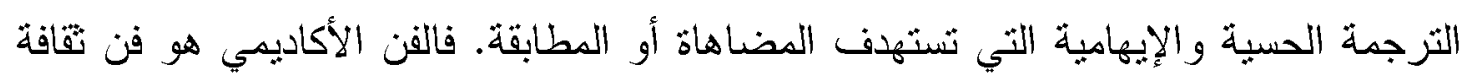

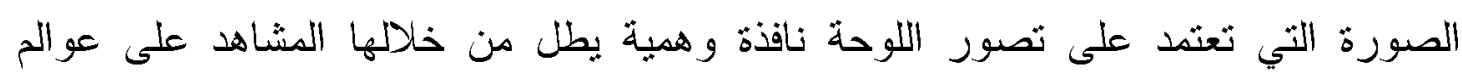

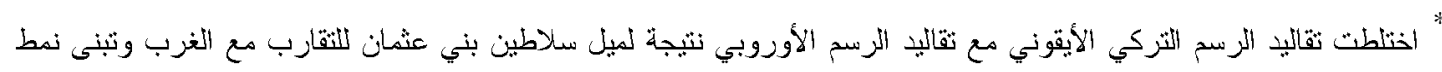

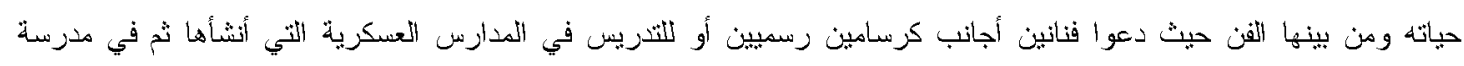

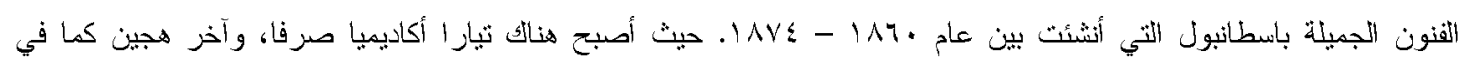
الحالة الكصرية. 
جسدها الفنان باستخدام حيل المنظور وتصوير البعد الثالث وتقنيات النظليل "كالكيار وسكوروا" " و والسوفو ماتو ".

وبينما نعند حضارة الثرق على الواقعية المعرفية فإن حضارة الغرب نعتمد على

حضارة الو اقعية البصرية.

ثاتيًا: رسوم ولوحات على الورق بالأحبار و الألو ان المائية و التذهيب:

و هي امتداد لتقاليد الرسوم التوضيحية في المخطوطات الإسلامية والقبطية تعتمد على التى

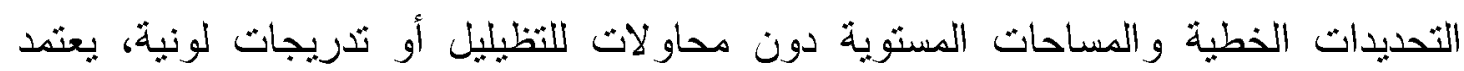

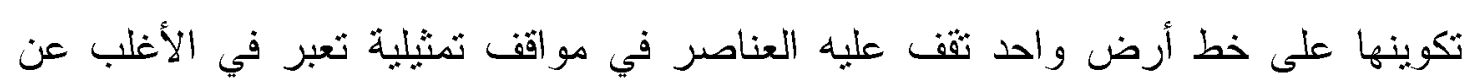

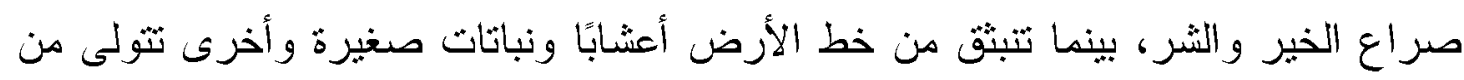

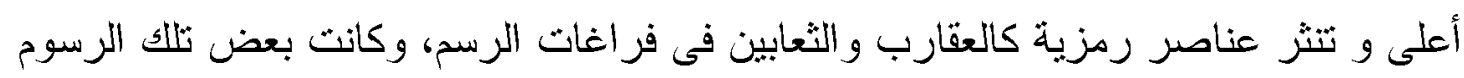

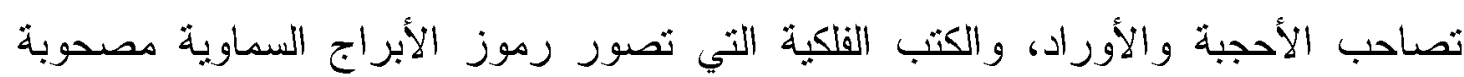
بكتابات وصفية في نكوينات منو افقة.

تتميز هذه الرسوم بالفطرية التلقائية أقرب في بعض جو انبها من رسوم الأطفال، لأن

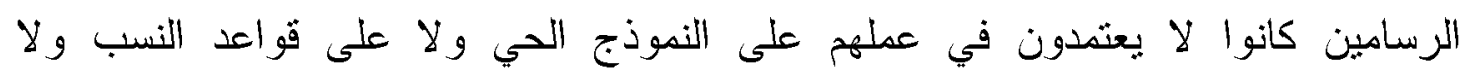
المنظور.

تضم هذه الرسوم أحيانا أنثالا هندسية فلكية ورموزا سحرية ورسوما بشرية طقسية

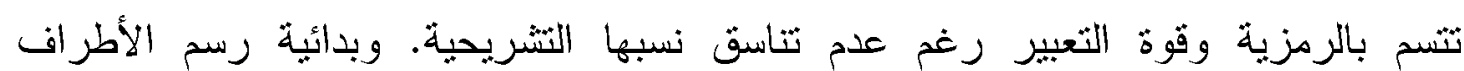

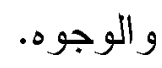

غير أن تلك الرسوم كانت تتميز بالاهتمام بالتكوين ونوزيع العناصر وربطها بالأفرع وأوراق الثجر والزهور فضلا عن نتاسق نوزيع الألوان، وكانت ثضم رسوما رمزية بانية

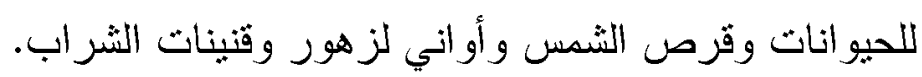

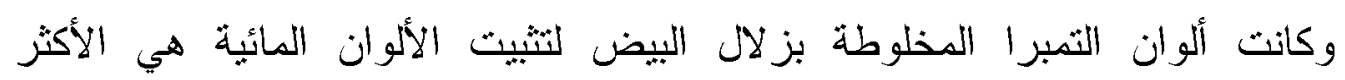

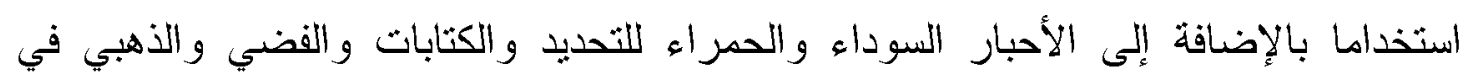
بعض المناطق.

وكان بعض الرسامين يوقعون بأسمائهم تحث هذه الرسوم التى كانت أحيانا ترسم.

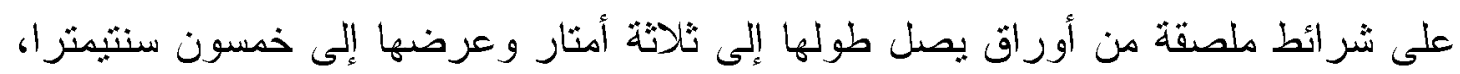

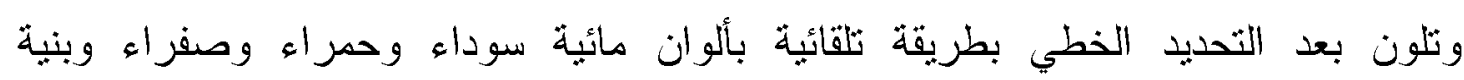
وبالإضافة إلى الذهبي والفضي. يمثل بعضها المواقع المقدسة لرحلة الحج، وبعضها لبها الآخر

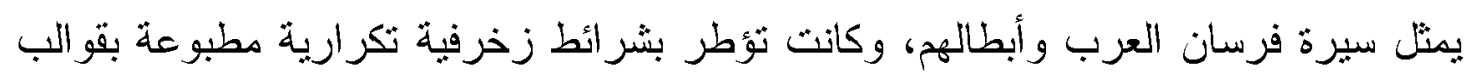


خشيبة بارزة. وكانت هذه اللوحات البانور امية تصور سلسلة من تتابعات قصصية وتلف على بكرتان داخل صندوق وتتحرك من اليمين إلى اليسار بيد اللاعب بينما يجلس الأطفال والكبار

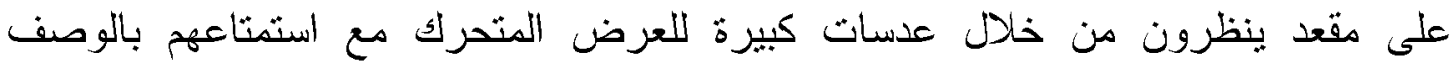

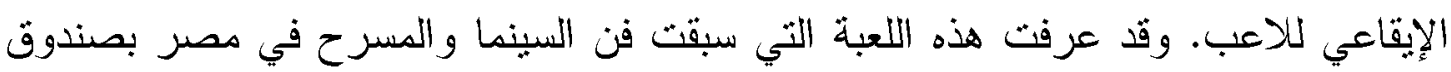
العجائب تارة، وصندوق الانيا تارة أخرى.

\section{ثالثًا: الرسوم التوضبحية المطبوعة في الكتب:}

مارس المصريين حفر القوالب الخشبية وطباعتها على صفحات الكتب ولوحات الأدعية والأوراد منذ وفي كتاب بانوراما فن الجرافيك المصري في القرن العشرين دراسة

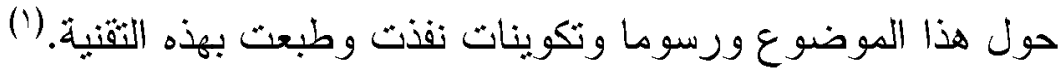

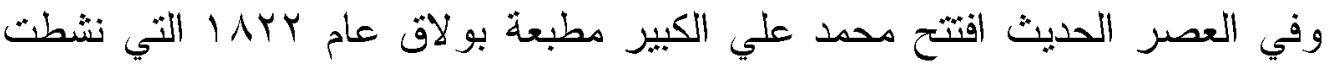

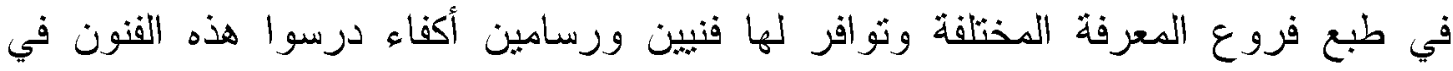
أوروبا وفي مصر، وفي عام AVV INV، أصدرت عن هذه المطبعة مجلة (السمير الصغير)

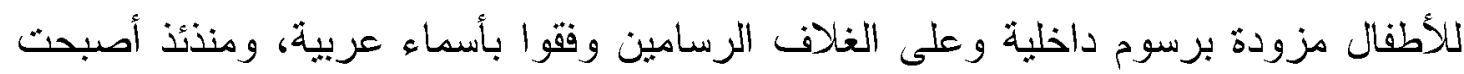

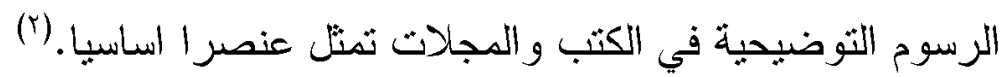
كانت الرسوم المطبوعة المشار إليها واقعية أكاديمية حيث تعلم الرسامين كما سبقت الإثارة في إيطاليا و فرنسا* * ، وفي مصر على يد معلمين أجانب في مدرسة العمليات ومدرسة الفنون و الزخارف فيما بعد.

وفي الوقت نفسه كانت المطابع الثعبية تنشر رسومًا ولوحات توضيحية ذات طات طابع

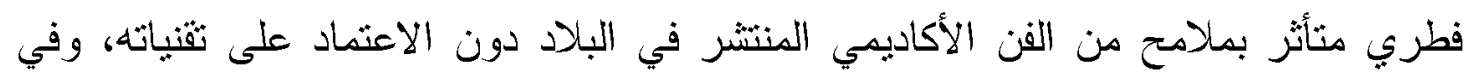

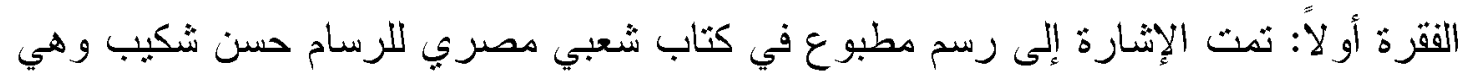
من هذه النوعية الفطرية، وكانت الطبعات الثعبية لكتاب ألف ليلة وليلة وكتاب كليلة ودمنة، وكتاب مقامات الحريزي تزود برسوم فطرية.

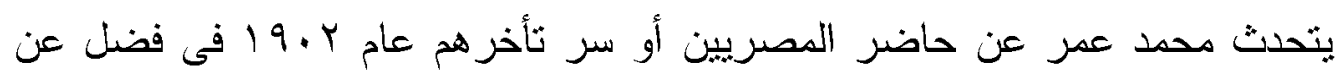

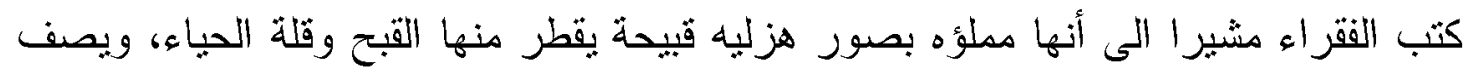

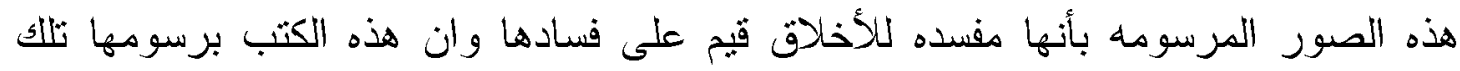

\footnotetext{
أستمر صندوق الانيا يطوف الثواز ع في المدن و القرى المو اللد حتى منتصف القرن العشرين نوع من الفرجة الثنعبية الجذابة.

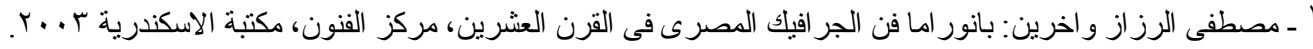

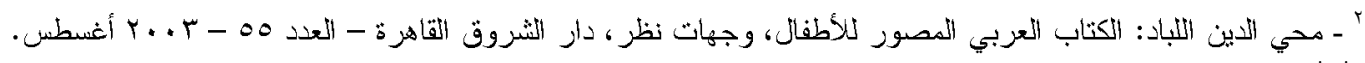

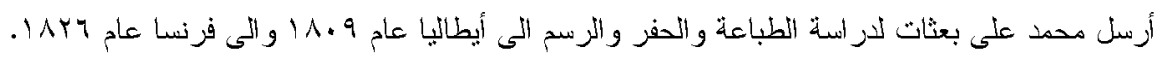




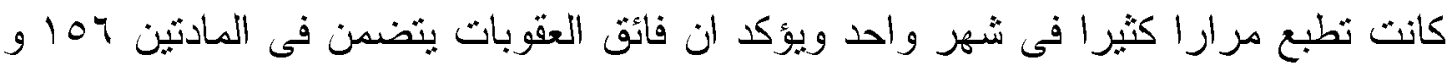

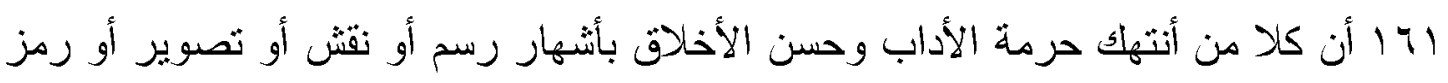

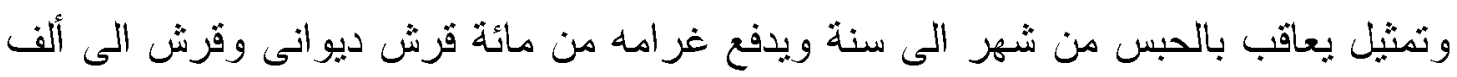

قرش

\section{رابعًا: لوحات الفروسبة وأبطال العرب:

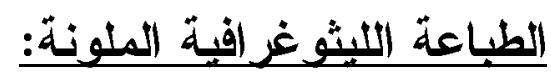

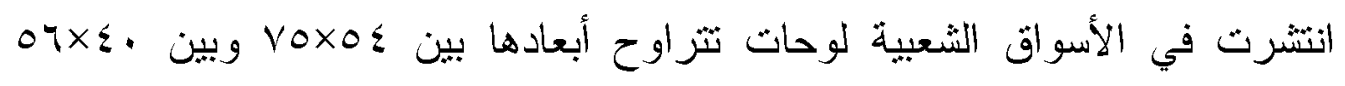

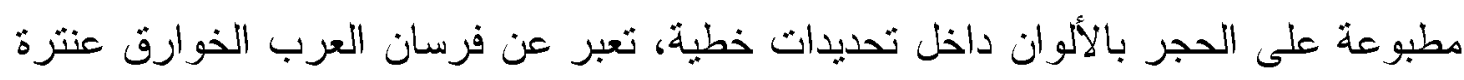

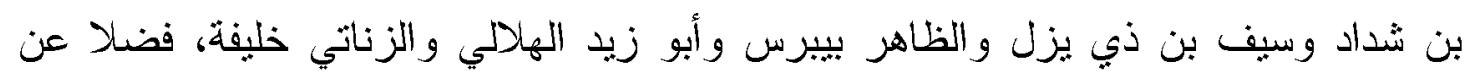

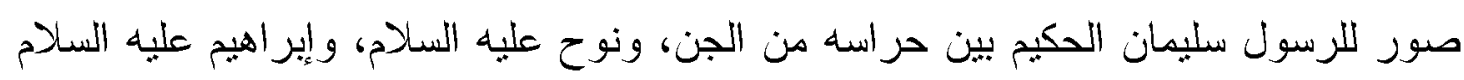

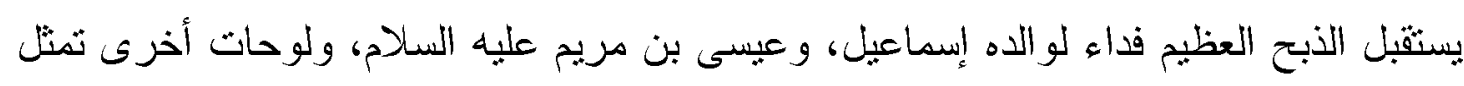

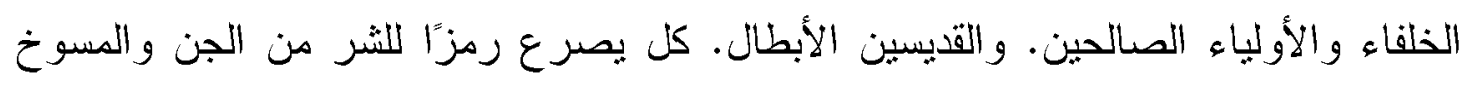

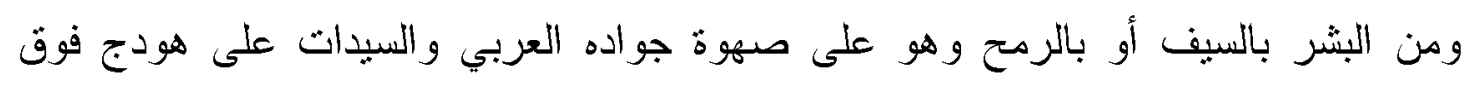

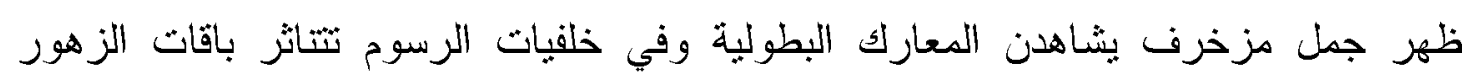
و الكتابات الشارحة التي تسمى كل شخصية بصفاتها المميزة.

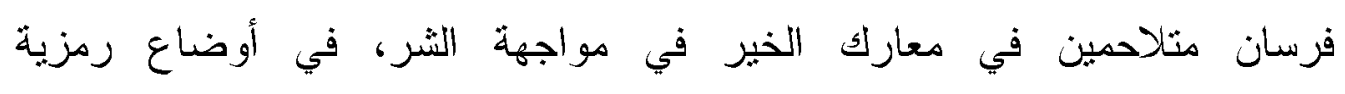
"ميلودر امية"، تتطاير فيها بقع الدماء وتسيل، وتتق الرؤوس إلى نصفين، حيث يحاكى الرسام

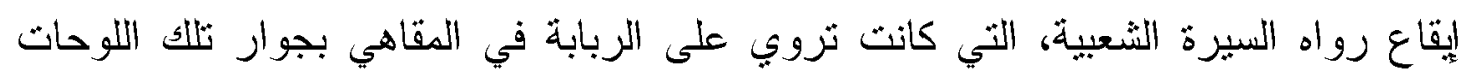
المعلقة على الجدران بكثافة.

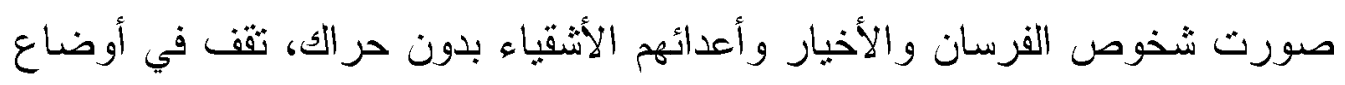

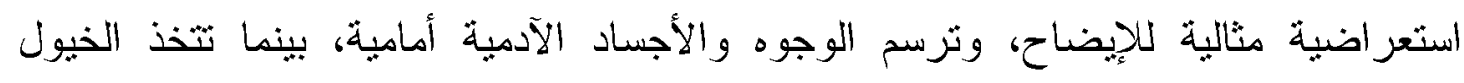

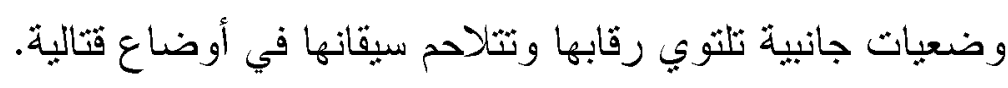

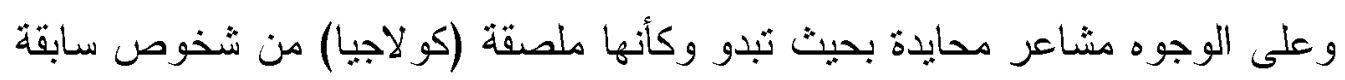

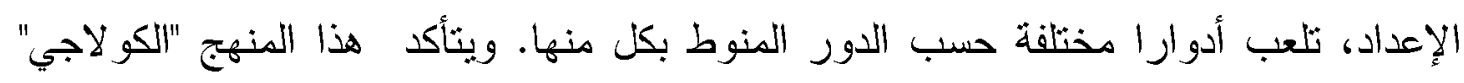

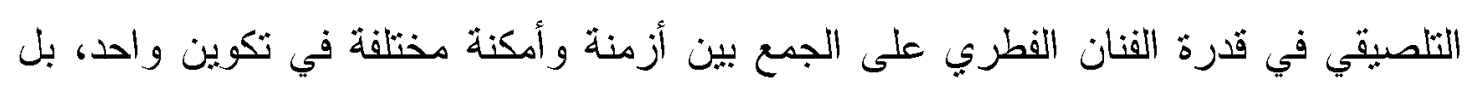
ويوفق بين ملامح اسلوبية مختلفة في نفس اللوحة. 
ويولي رساموا ثلاك اللوحات أهمية كبيرة للملابس وأغطية الرأس وزخارف السروج

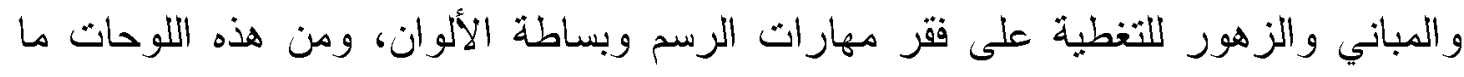
يسجل الفنان تحته اسمه و المنطقة الني بها محترفة.

خامسيًا: الأبقونات القبطية: لفئه

كانت الأديرة والكنائس الكبيرة في مصر ثمانية مؤسسات حريصة على التراث

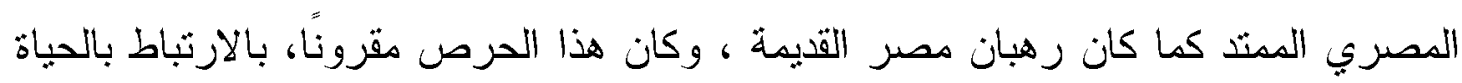

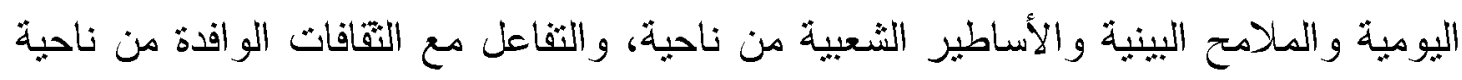

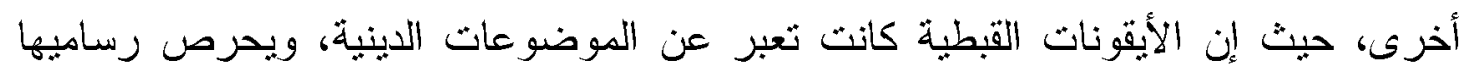

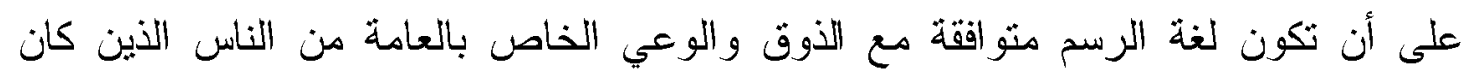
هؤلاء الرسامين أنقسما من أوساطهم الاجتماعية المتو اضعة.

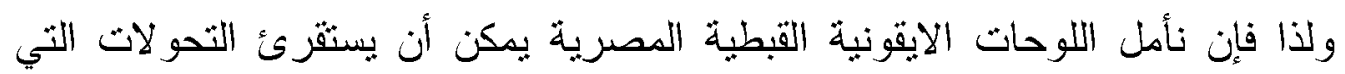

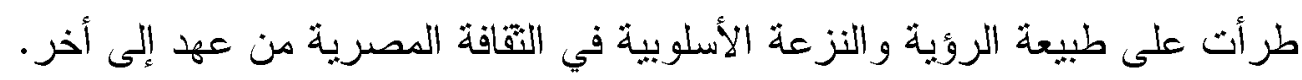

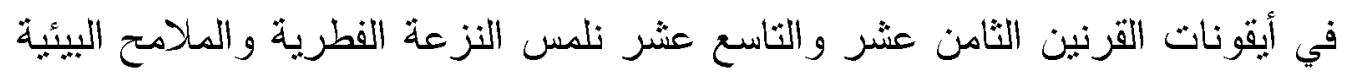
واستخدام الكتابات العربية وحدها أو بمصاحبة ترجمة من اللغة القبطية لتوضيح الرسوم والتعريف بكل شخصية، حيث يوضع اسمها بالقرب منها، كما في اللوحات المطبوعة ترجة

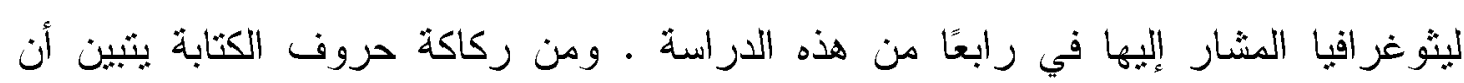

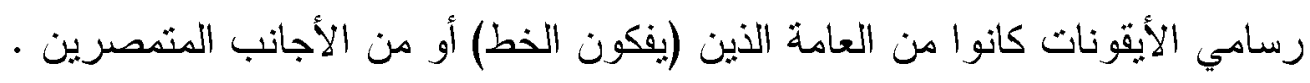

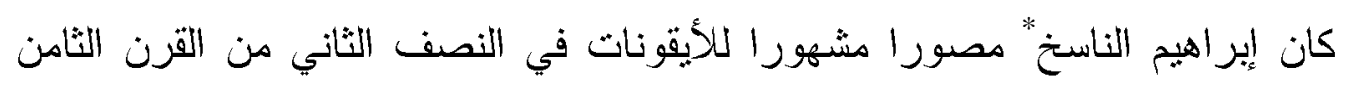

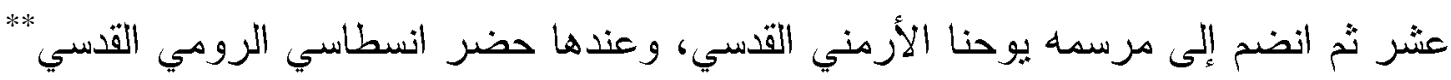

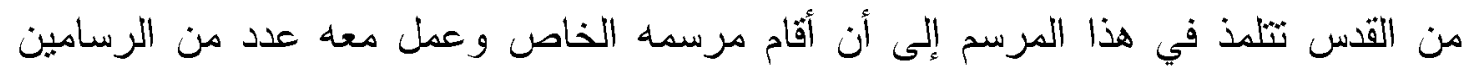

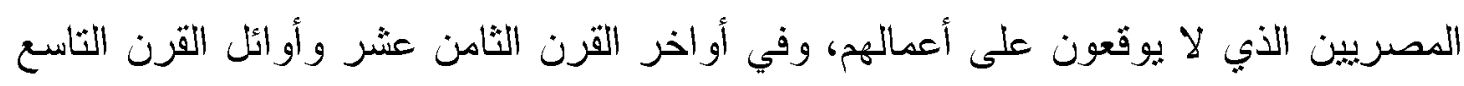

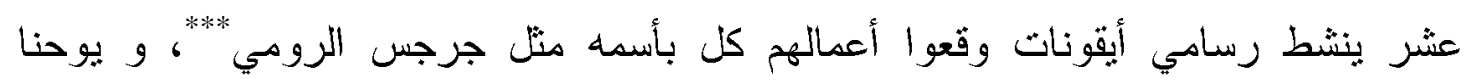

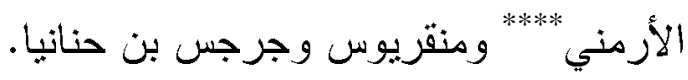

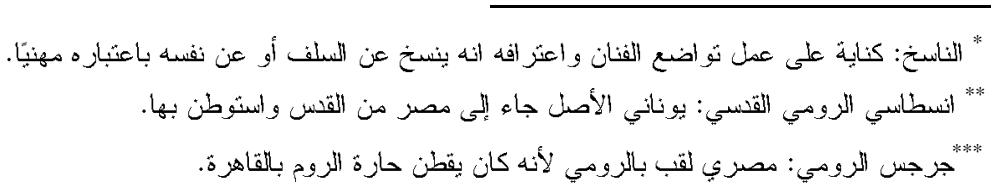

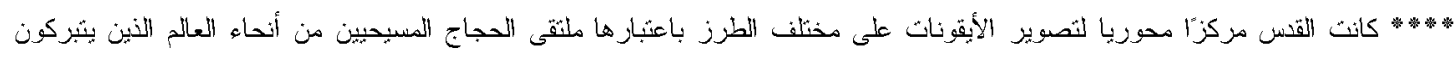

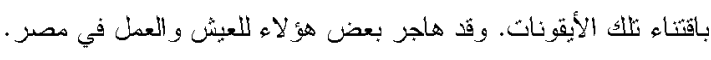


تثراوح أساليب التصوير في ثلاك الفترة المرسومة بالتمبرا على الألواح الخشبية بين

تقليد الطر از الييزنطي و الروسي كما في أعمال جرجس بن حنانيا، وجرجس الرومي.

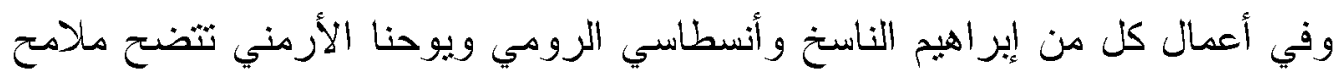

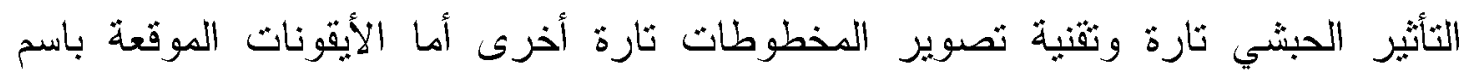
منقريوس فهي طراز مصري قبطي ينسم بالتلقائية والبساطة والرمزية، ومن الأساليب

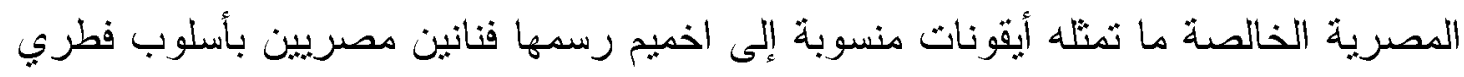
مع نزعة زخرفية رمزية وقوة تعبير تعد امتدادا للفن القبطي.

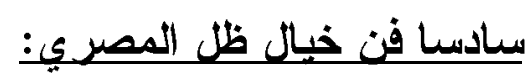

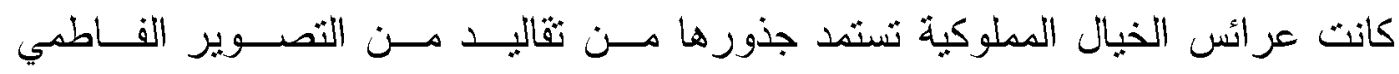

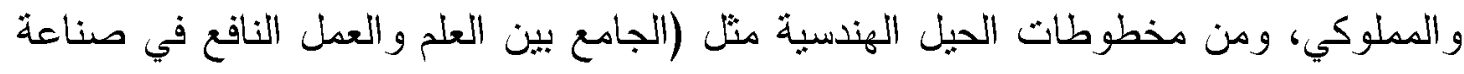

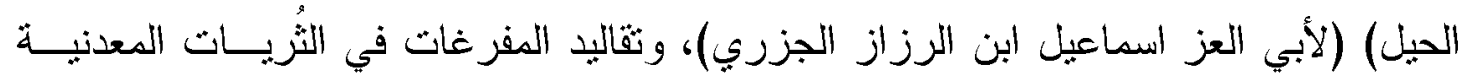

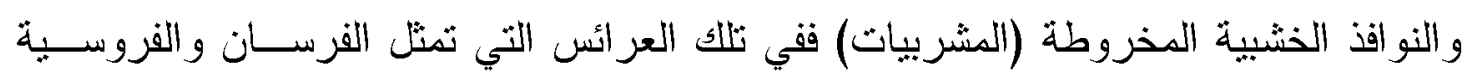

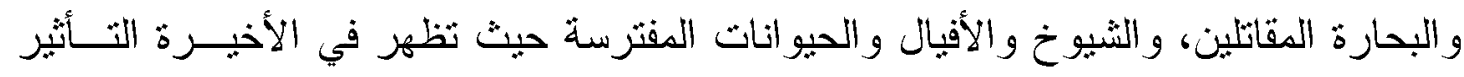

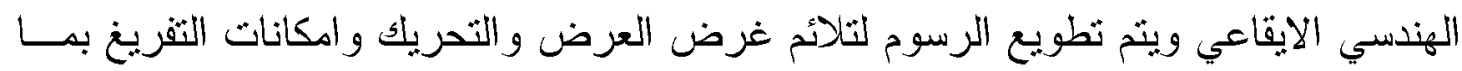

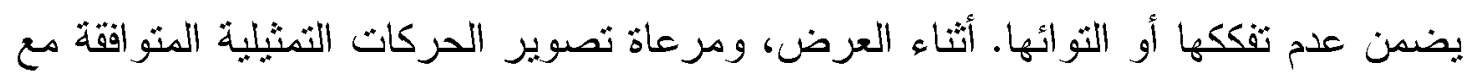
أدوار النصوص الموضوعة.

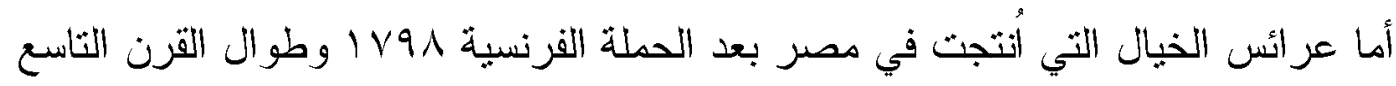
عشر، فكانت تتسم بالطابع الزخرفي المتوارث عن النماذج القديمة (المملوكية)، تداخلت دعهال

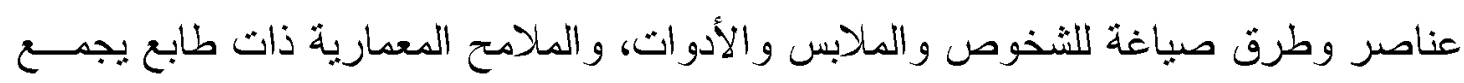

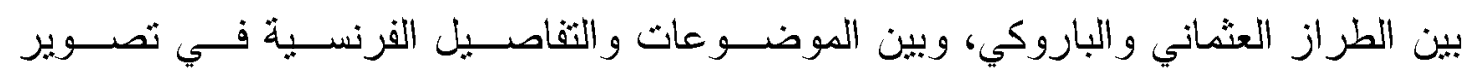
الثخوص و الأثاث و الملابس.

كانت فرق الخيال المصرية الجوالة في القرن التاسع عشر ثمانية وعشرون دوراً نثثيلياً،

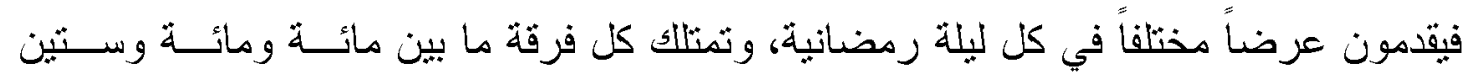

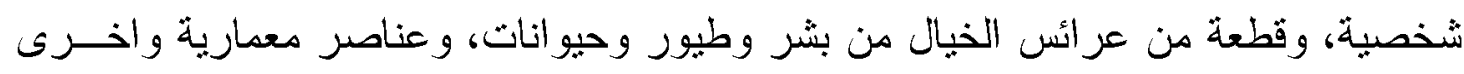

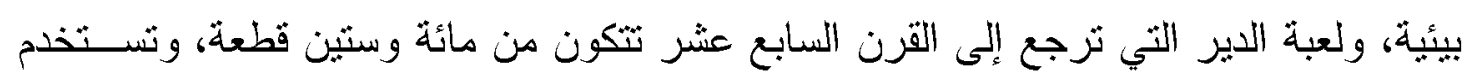

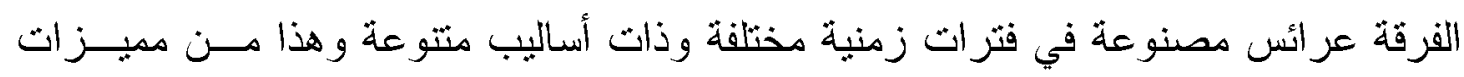

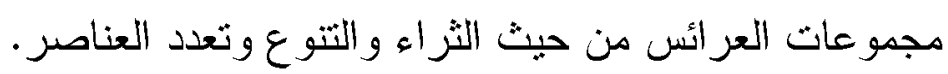

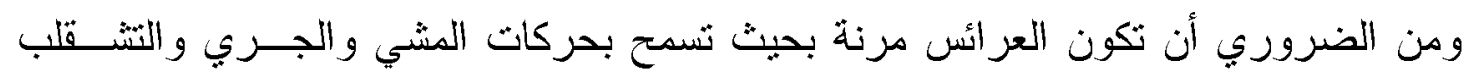

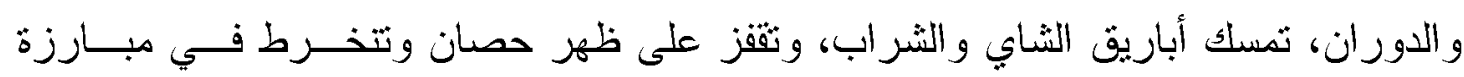


بالسيوف وتؤدي حركات بهلو انية، وتجلس بأدب على مقعد فضلاً من ثمثيلها الحياة اليوميــة.

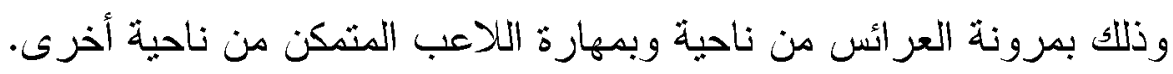

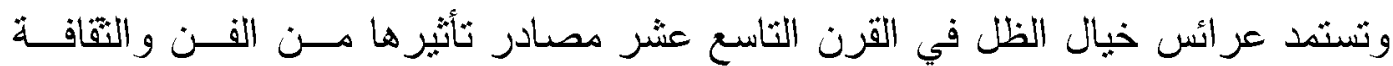

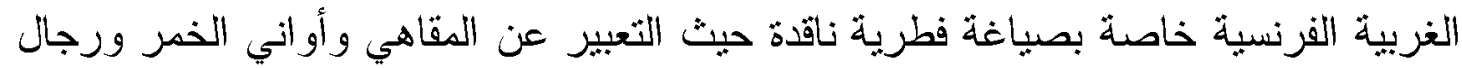

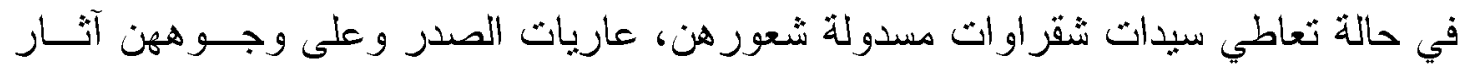

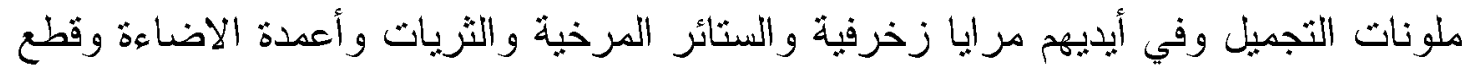

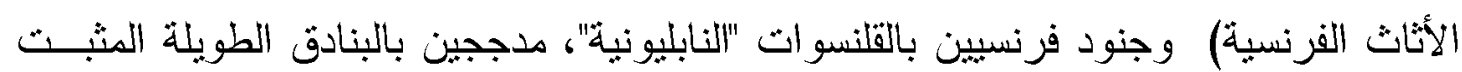

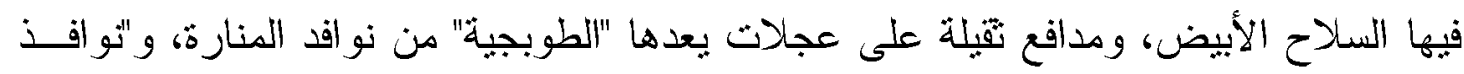

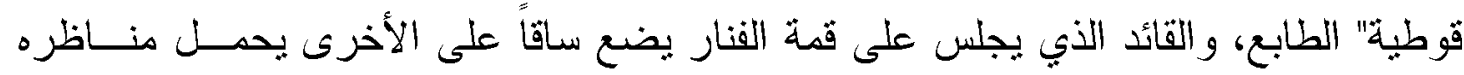

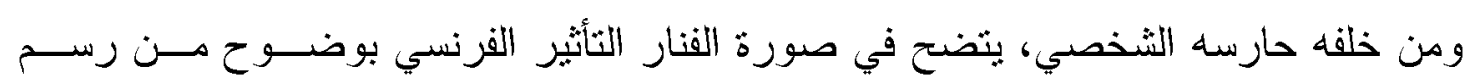

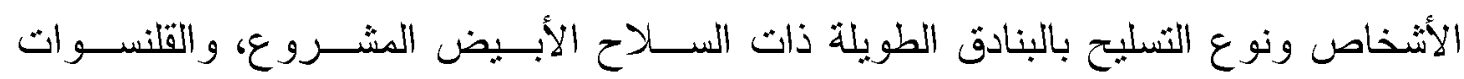

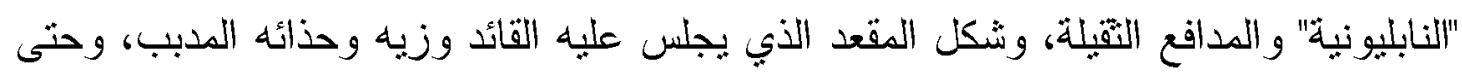

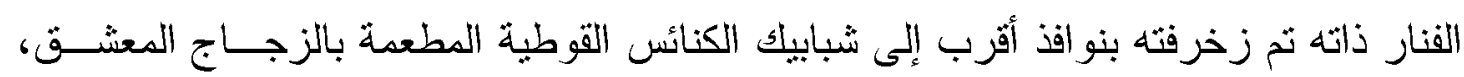

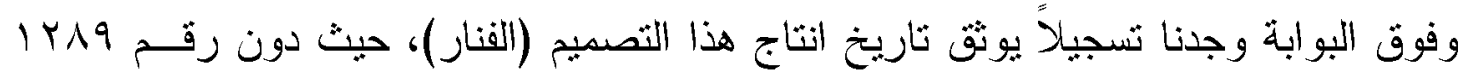

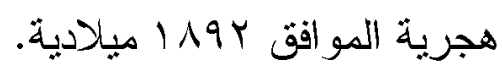

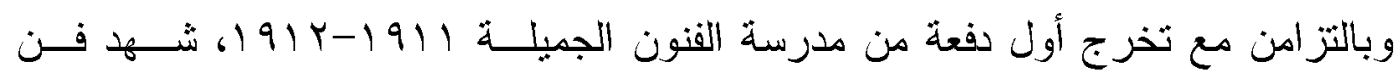

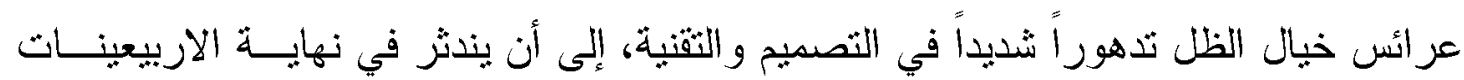

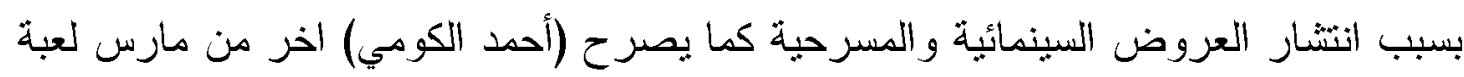

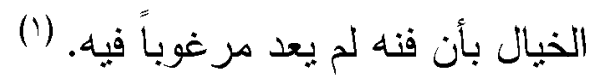

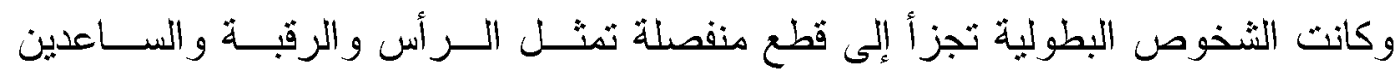
و العضدين، والكتف، و الجزء الأسفل. بينما كانت الثخوص الثانوية تصنع من قطعة واحسندة

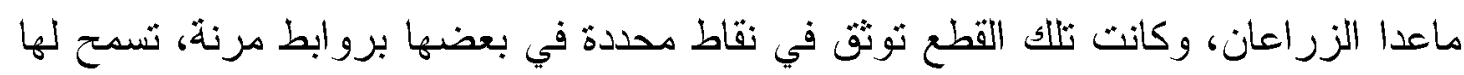

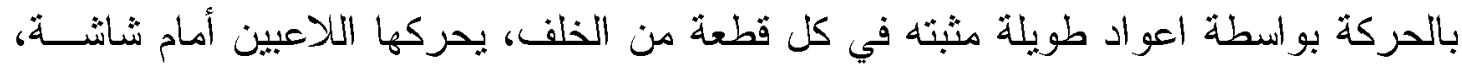

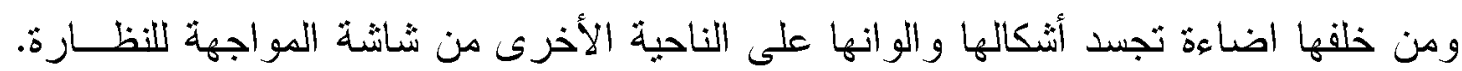
و أثناء النحريك يثم نشغيل تكوينات حركية منغيره بالعر ائس المخصصة لكل دور.

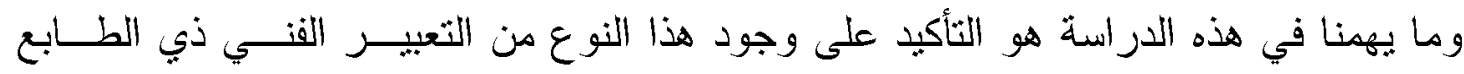

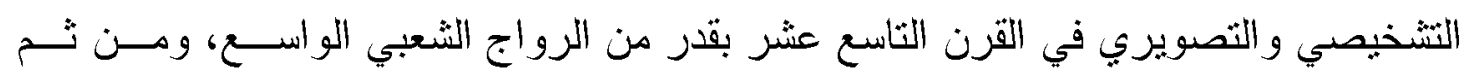

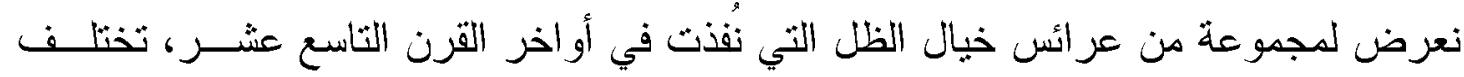




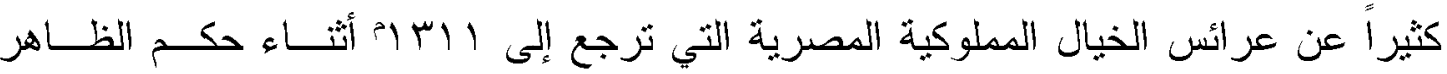

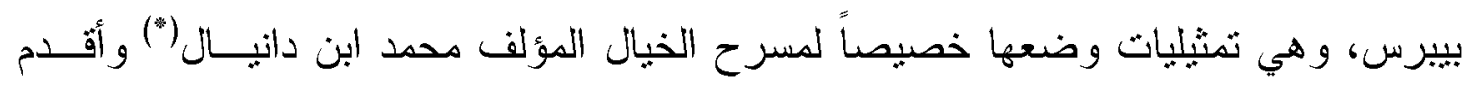
العر ائس.

التي عثر عليها ترجع إلى عام . YO ا، اكتشفها لا عب خيال ظل اسمه (حسن القتــاش)

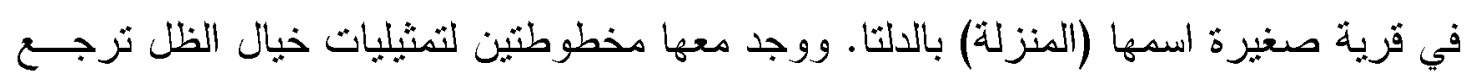

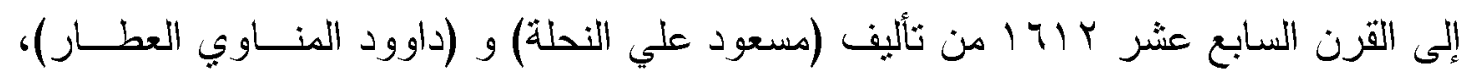
وقد استغل القشاش وولده (درويش) هذه الاكتثافات في إعادة إحياء فن خيال الظل، وصنعوا

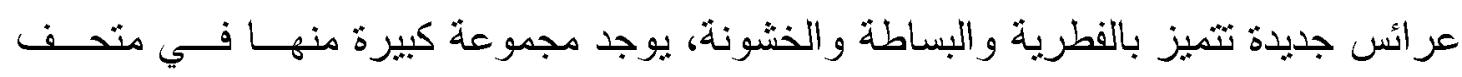
الاتتوجر افي التابع للجمعية الجغر افية بالقاهرة.

تثتوع شخوص خيال الظل التشمل عسكر بملابسهم الرسمية، وفلاحين ونجارين وملاحين

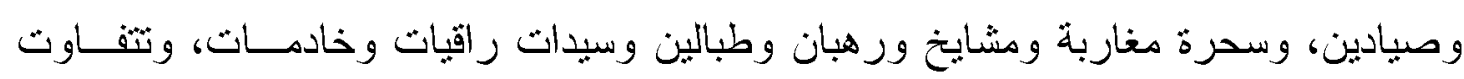

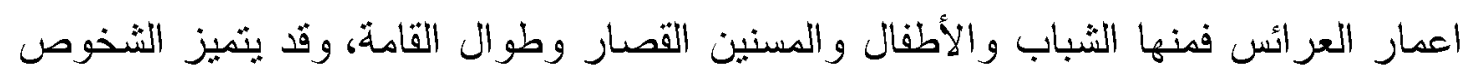

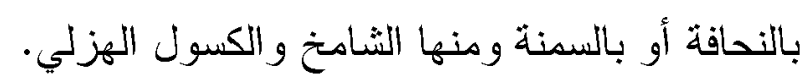
وتتسم رؤوس عرائس خيال الظل بثمايز الثخصيات والتعبير عن الأدوار، ومعظم أوجه

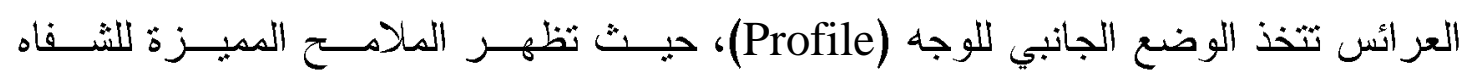

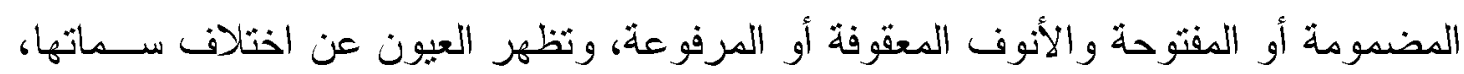

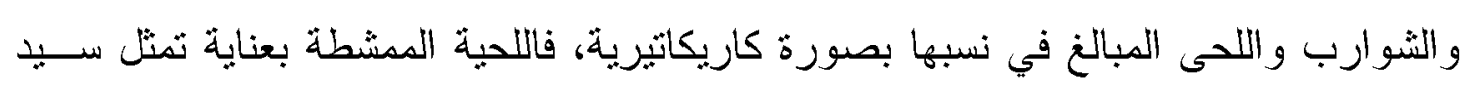

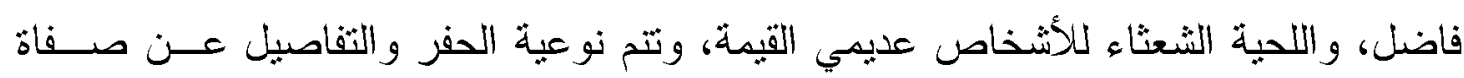

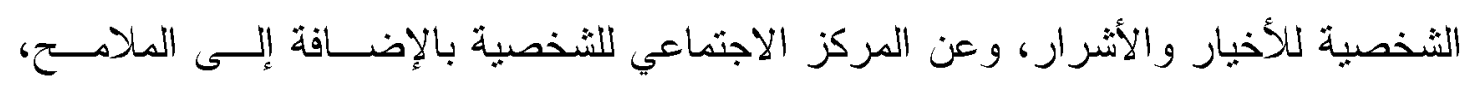

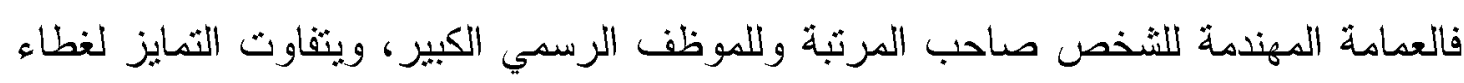

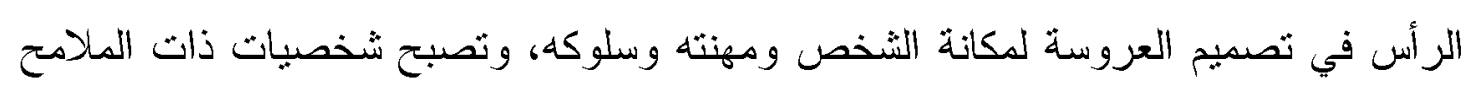
المميزة علاقات محفوظة للجماهير ، ونساهم في وضوح المغزى من الرواية.

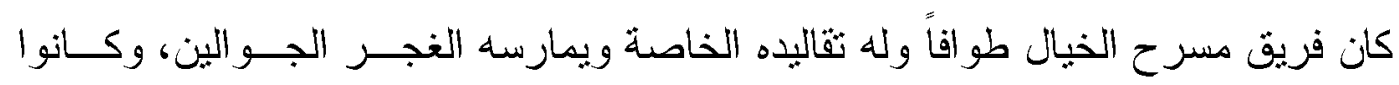

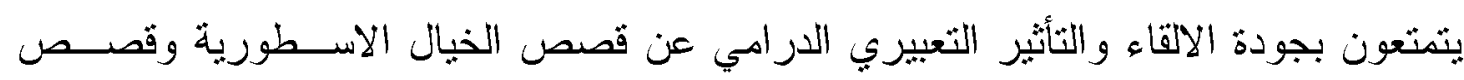

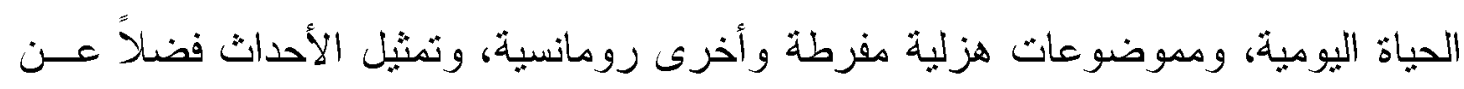
مهارة بارعة في تحريك العر ائس خلف الثانشة المضيئة.

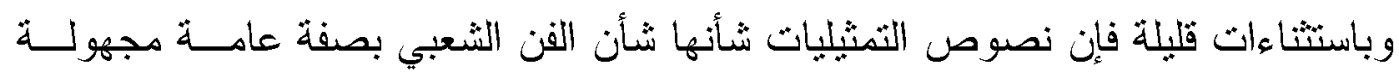

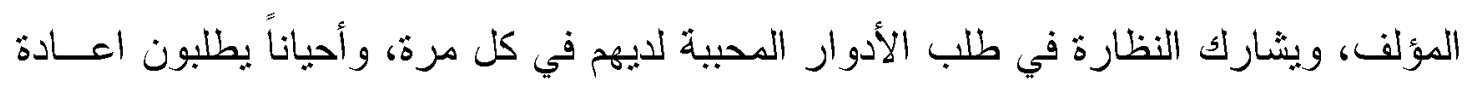

(") التمثيليات هي: طيف الخيالـ عجيب وغريب- والمُتئيم. 
عرض ما يسنملحونه من ادوار مرة بعد الأخرى، ومن التمثليات الأكثر شعبية تمثيلية العجيب و الغريبب وتضم سبعة وعثرين من أرباب الحرف يستعرضون مهار اتهم النوعية، وروايـة

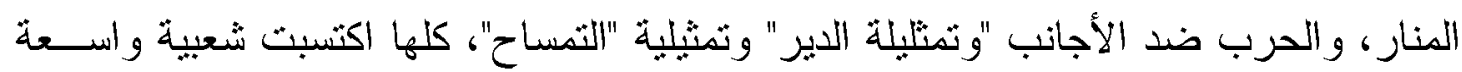

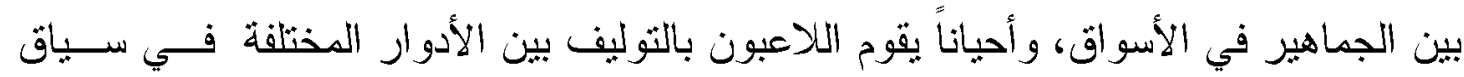
متجانس. وكان مثهد عروض عرائس الخيال شائعاً في شوار ع القاهرة في غضون القرن التاســع عثر حيسث وظفت روايات ابن دانيال التي كثبها في القرن الثامن عثر وعروض مســود على النحلة، والريس داوود المناوي العطار في القرن السابع عثر . وقد واصل صناع مسرح خيال الظل ابتكار الحيل الذكية، المؤثزات الصوثية والحركيـة و الضوئية والموسيقية، لتأكيد الجو الدر امي الاسر لعروضهم الفنية التي نمثل مشاهد من الواقع

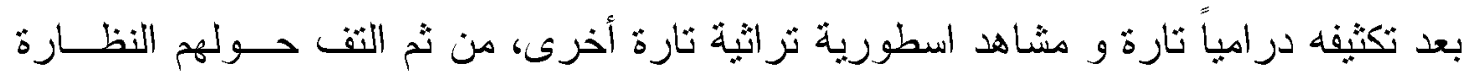
بشغف وحماس. ويتم تتظيف خليفة مسرح خيال الظل من ور اء الثاشة بصورة نمطيــة حيــث يثضــمن مثاهد لتفاصيل معمارية اسلامية- بو ابات- عقود - منار ات- مئاذن وقباب وجدران مزخرفة،

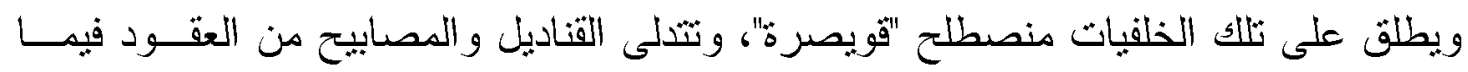

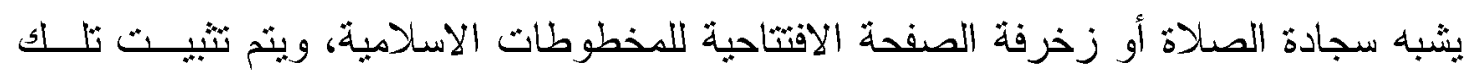
القطع بالإضافة إلى قطع الاثاث بدبابيس خلف الثاشة مباشرة. ونتكون فرقة ممثلين مسـرح الخيال من خمسة أشخاص، بالإضافة إلى أربعة عازفين للموسيقى. وفي الأصل كانت الدفوف وحدها مصاحبة للاداء الثمثيلي والحركي، ثم صــاحبها آلات أخـرى كـالطبول و الصــنج و المزمار منفرد ومزدوج البوصات، إلى جانب التصفيق الإيقاعي وثقليد أصوات الحيوانات أو أصوات الضرب و الشغب، بحيث تتدمج في سياق العرض وتثو افق مع أحداثله.

خلاصة كان الفنانين الوطنين في موقف بين فنونهم الترانية، الثعبية خاصةً وبين نزعاتهم الفطريــة،

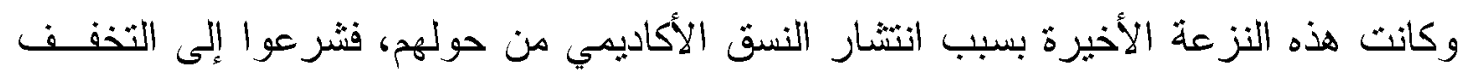

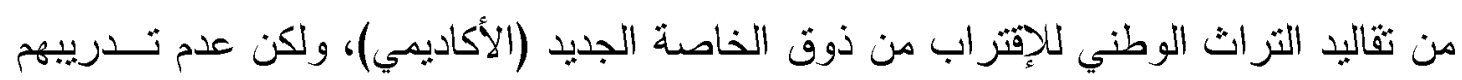

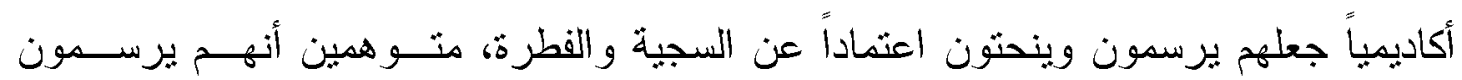
كالأكاديمين، فأصبحوا بذلك مقسمين بين ثلاثة و لاءعات، الو لاء للنبع الثز اثي الممت و المثراكم

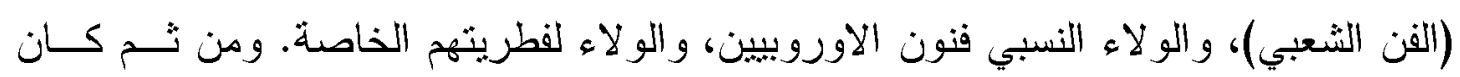


انتاجهم الفني معبراً عن هذا التوزع في النظم البصرية التزاثية والأكاديمية و الفطرية رغم ما فيها من مفارقات واسعة.

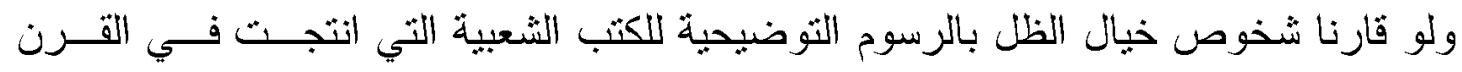

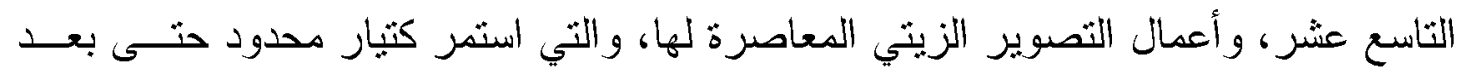

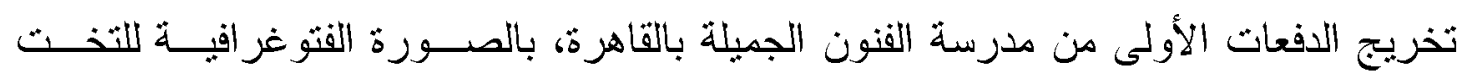

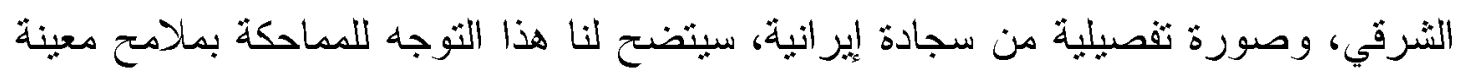

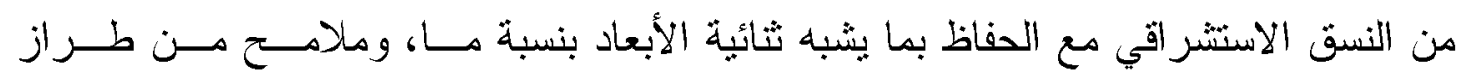

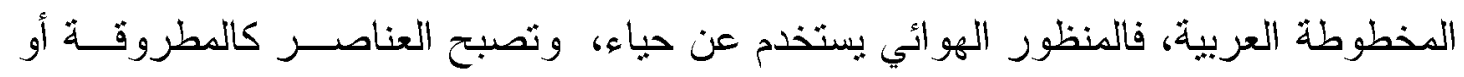

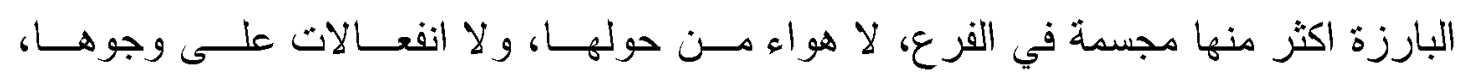
وحركاتها تمثيلية اصطلاحية ثبوتيه،

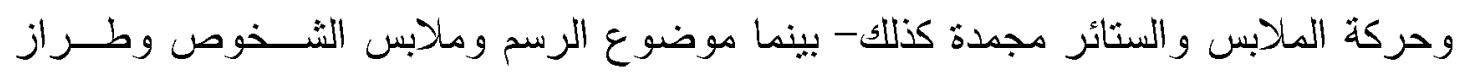

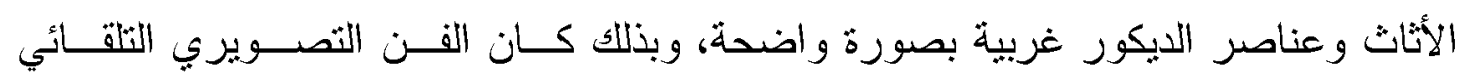

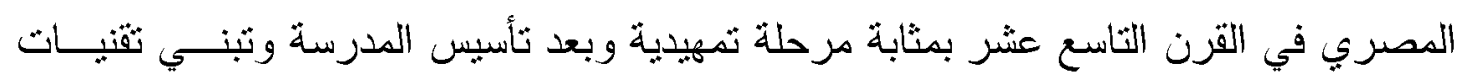

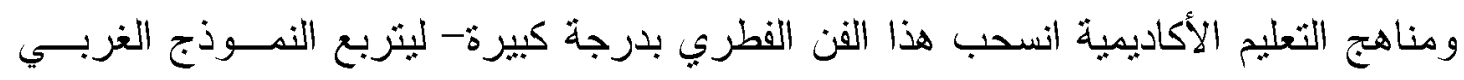

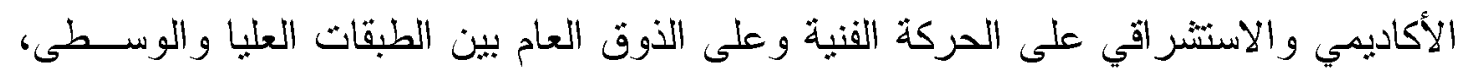

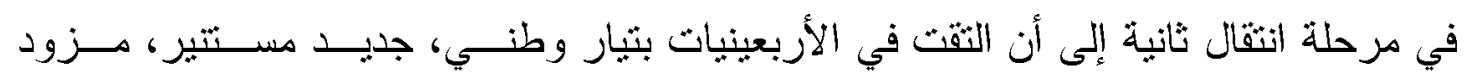

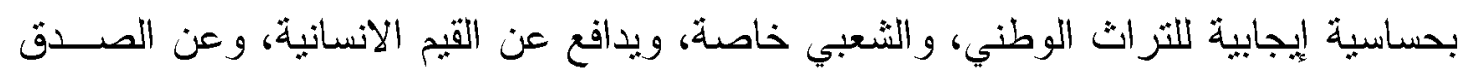

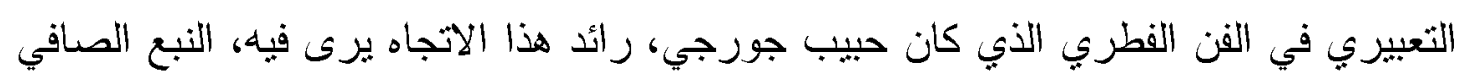

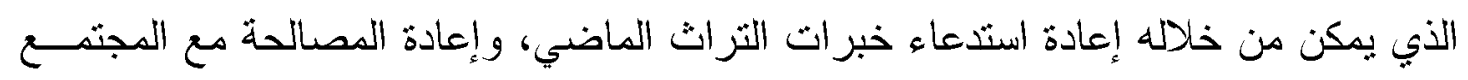

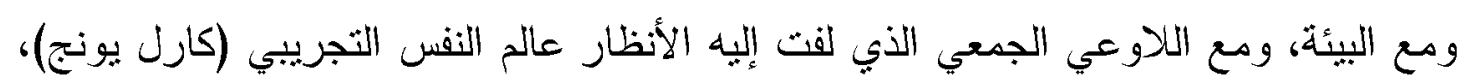

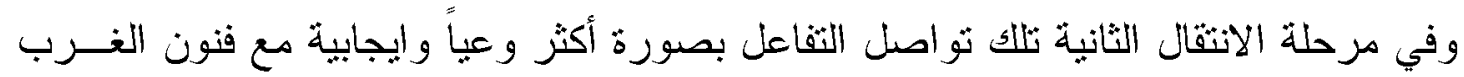
الثقدمية وليس الأكاديمية الجامدة. 

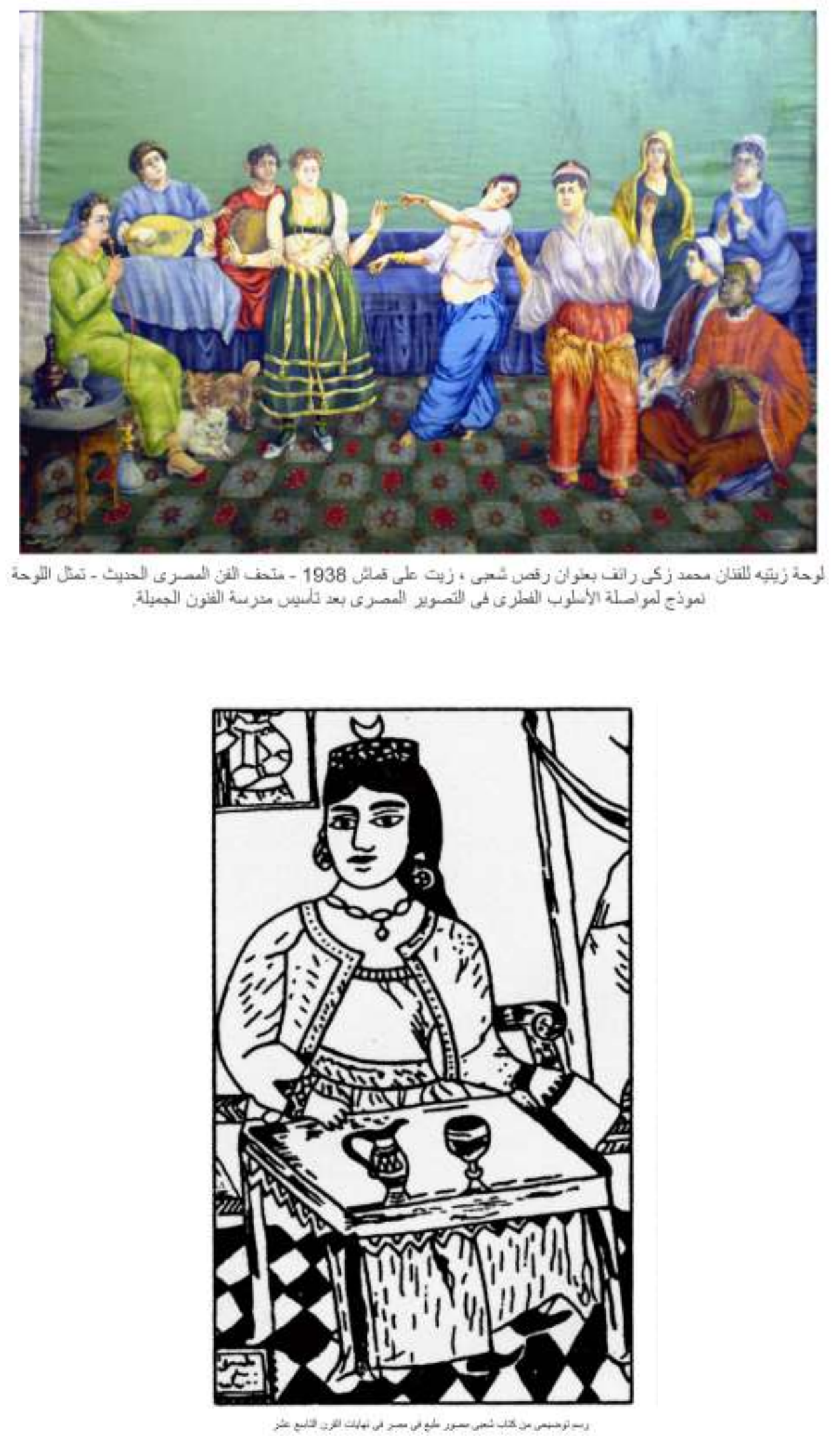

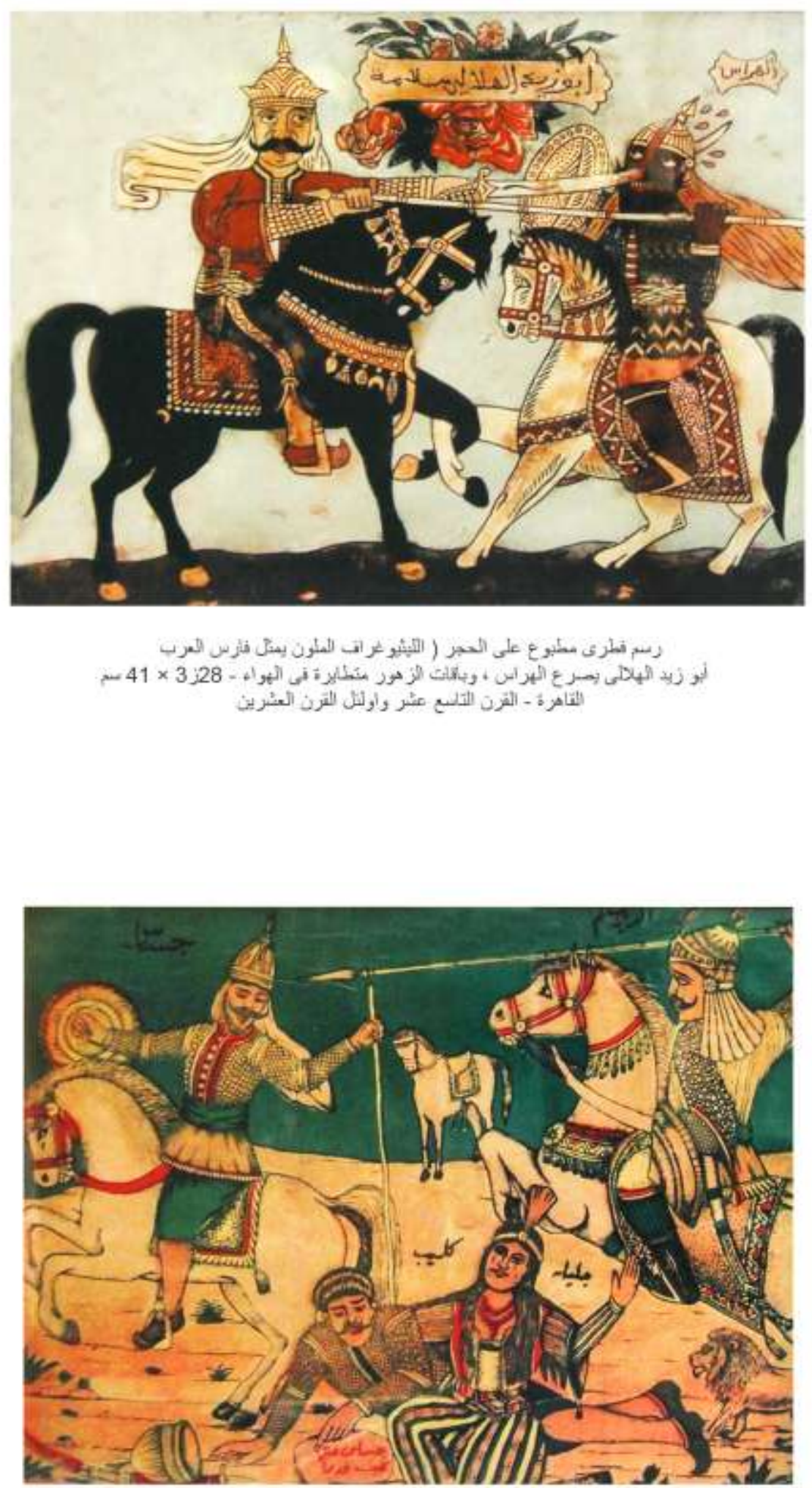

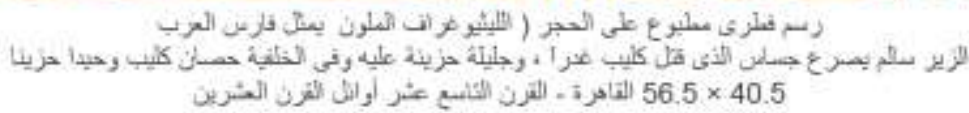




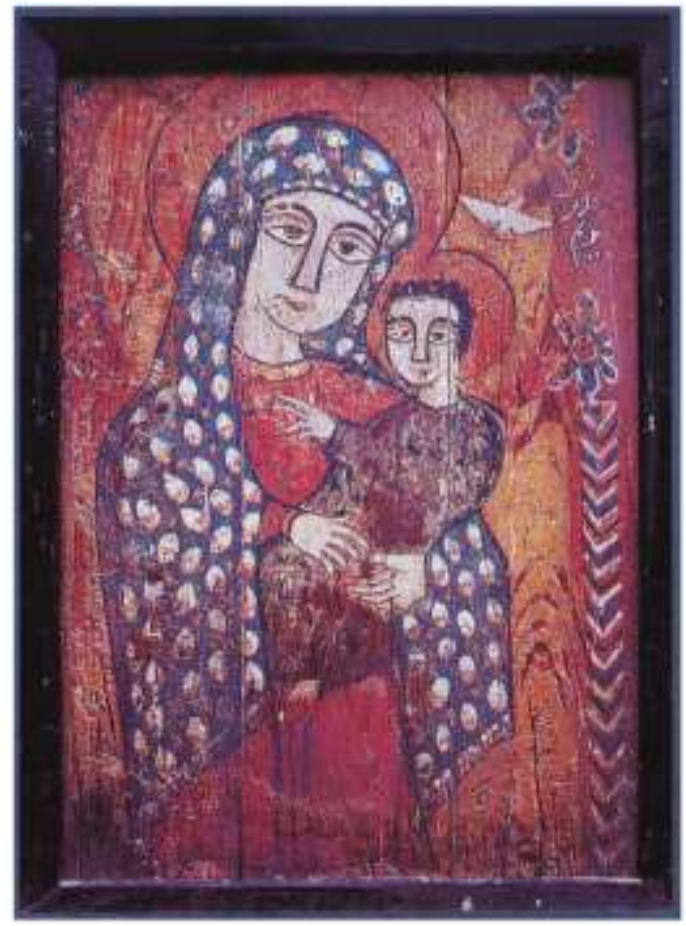

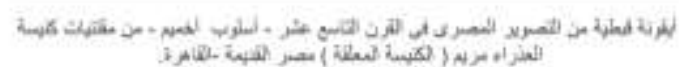

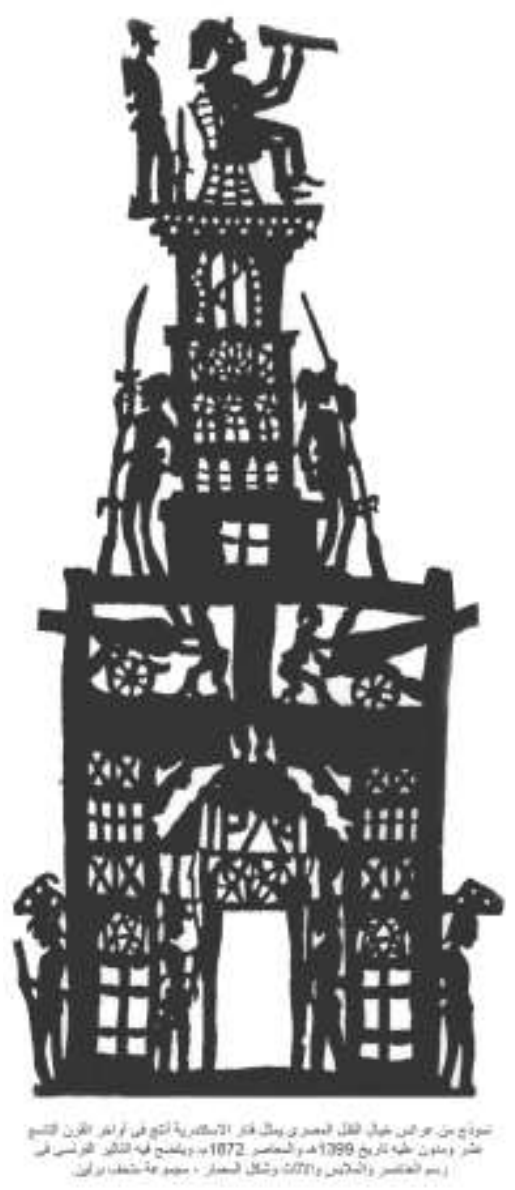

(AmeSea DataBase - ae - Jan. 2015- 0001) ro 


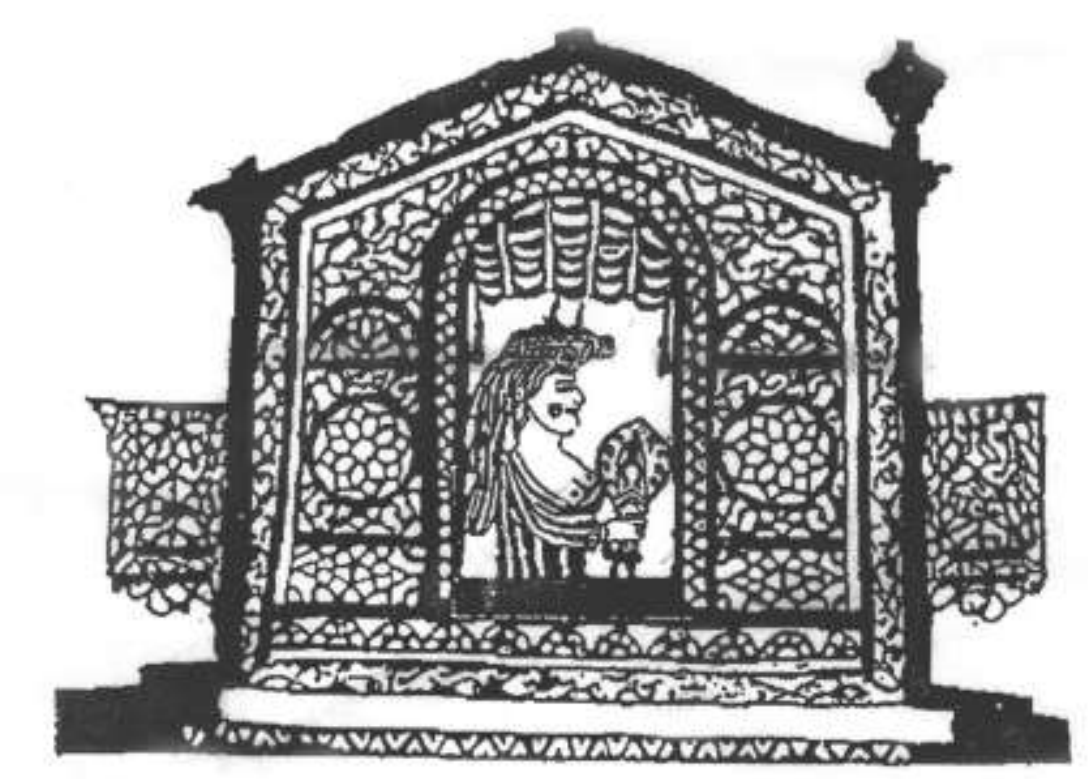

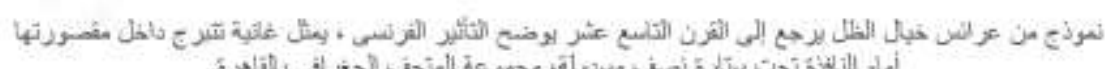

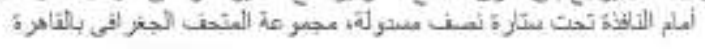

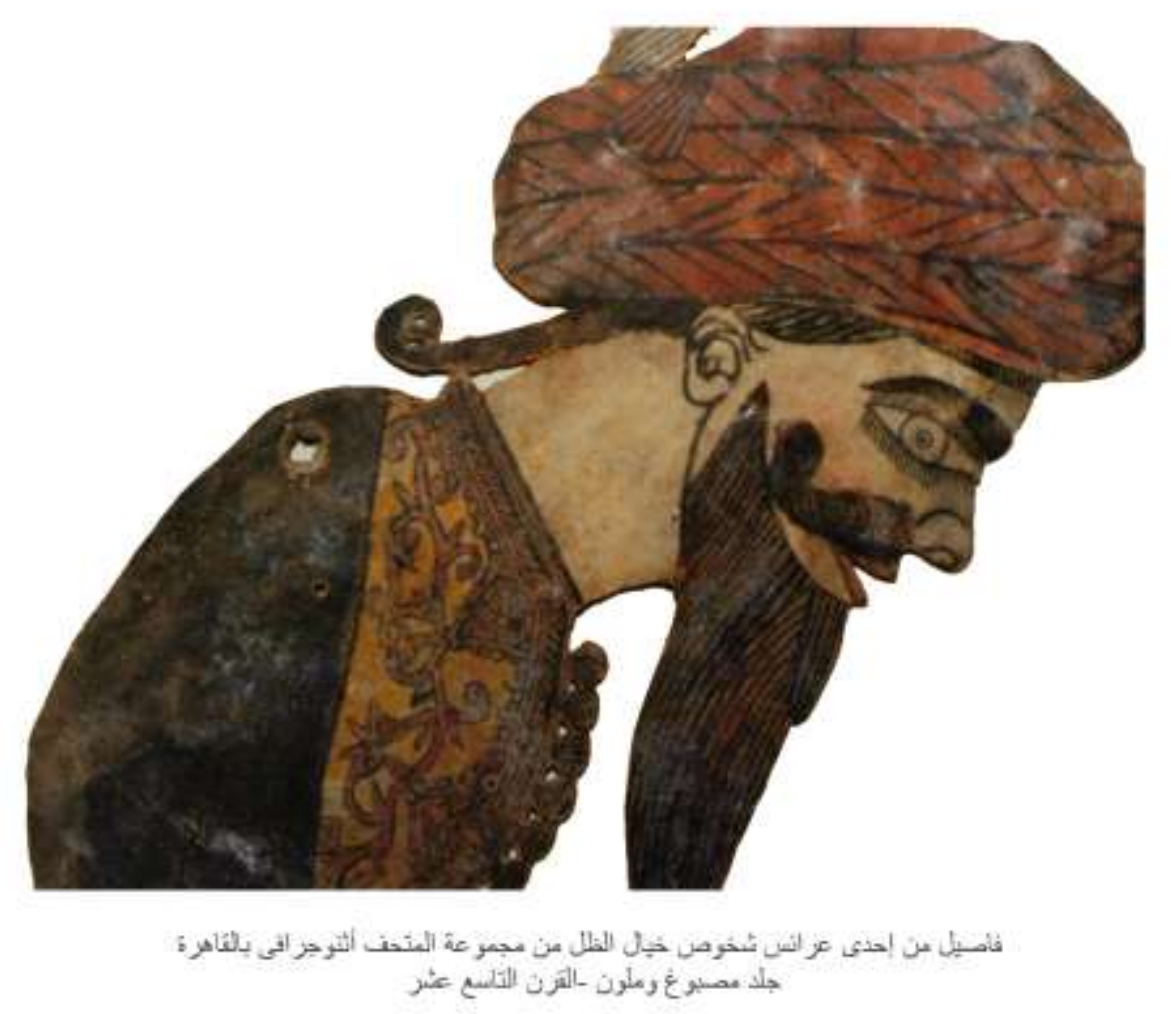

(AmeSea DataBase - ae - Jan. 2015-0001) 


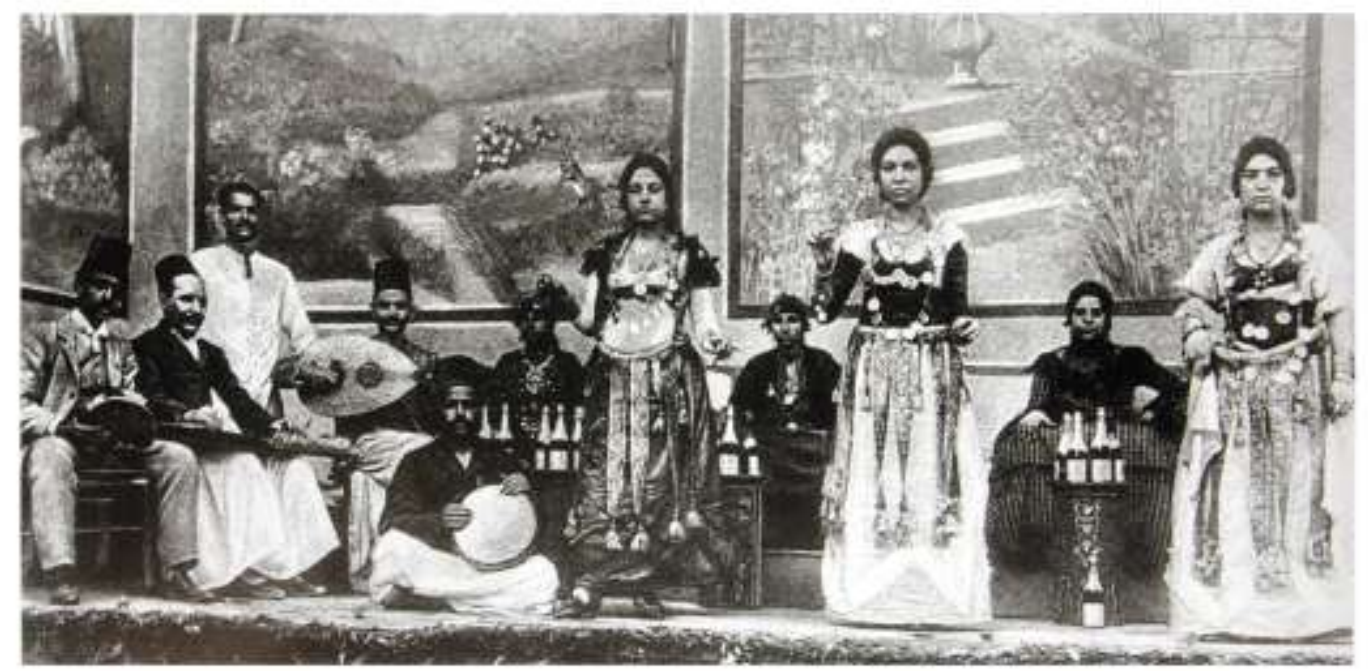

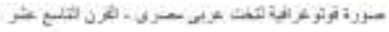

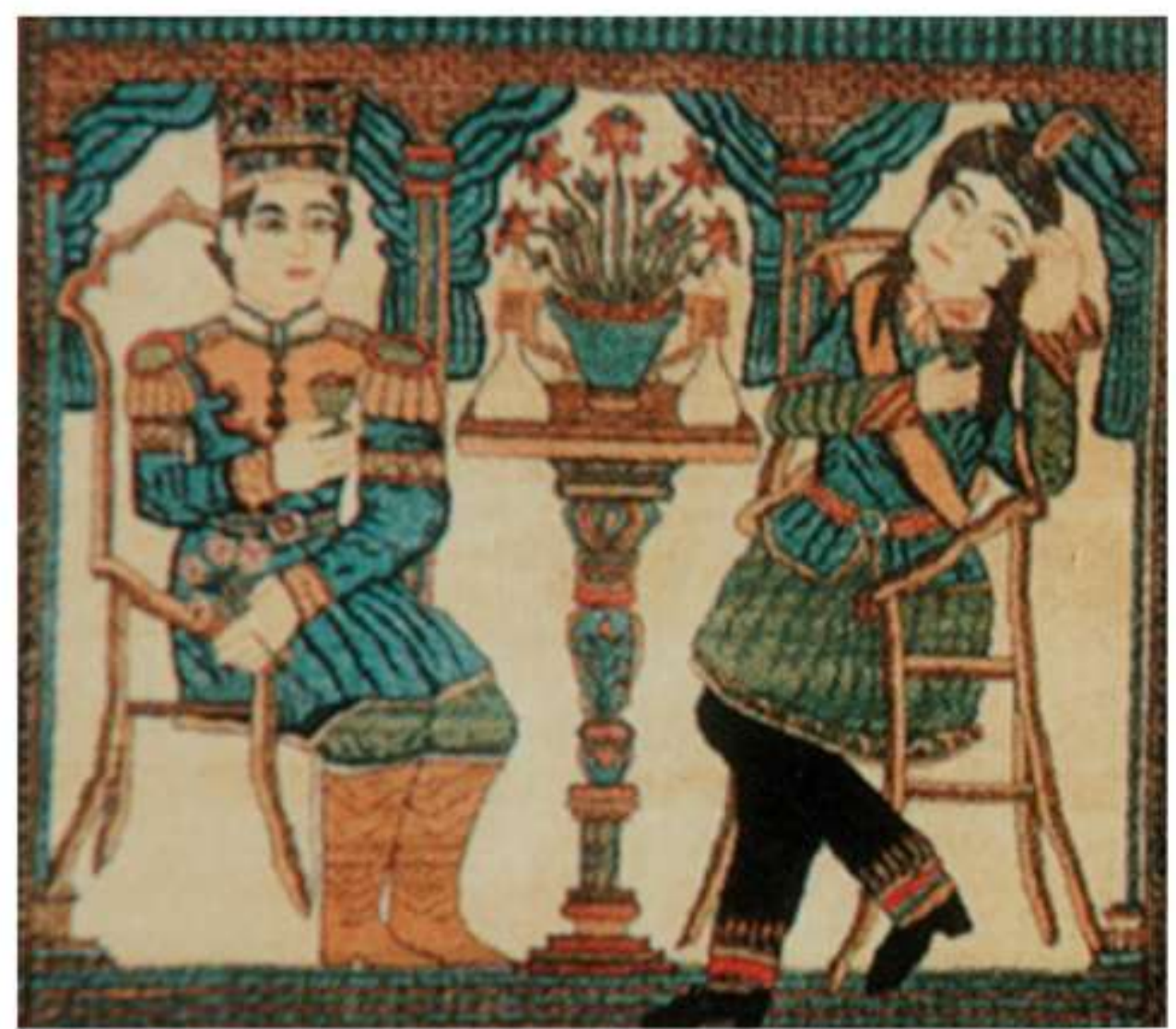

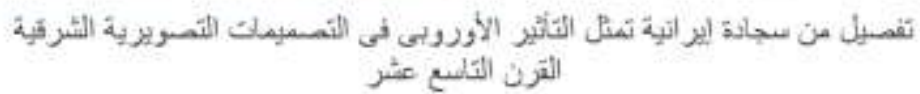


أحمد تيمور : خيال الظل و اللعب و التماثيل المصورة عند العرب، دار الكتب العربي،

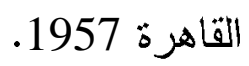

بول كاله: خيال الظل فى القطر المصرى، مجلة الادب و الفن، الجزء الرابع، لندن

$.19 \leq \varepsilon$

جين فر انكو: دروب إلى فن جديد، مجلة اليونسكو، العدد 130، ابريل 1972.

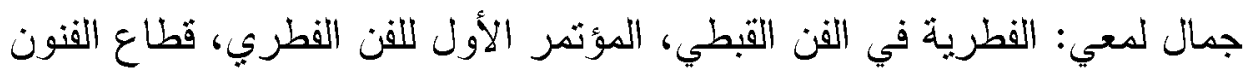
التثكيلية، وزارة الثقافة، القاهرة، 2002.

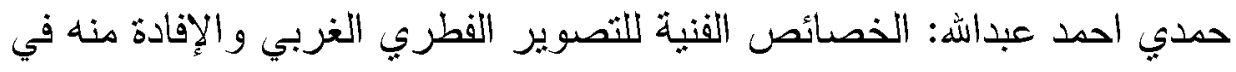
تدريس التذوق الفني لتناميذ المرحلة الثنانوية، رسالة دكتور اه غير منشورة، كلية التربية الفنية، جامعة حلوان، القاهرة، 1978.

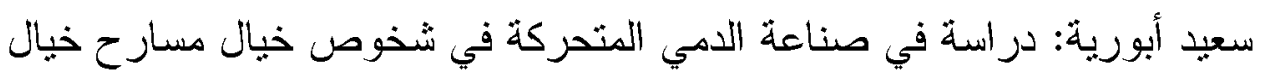

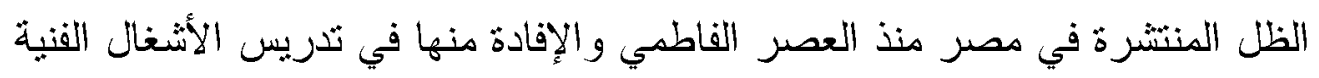
و النعبية في كلية التربية الفنية. رسالة ماجيستير غير منشورة: كلية التربية الفنية. جامعة حلوان 1984. سعيد أبو رية: نماذج معاصرة لدمي خيال الظل كمدخل توصيلي لخبر ات تعليمية

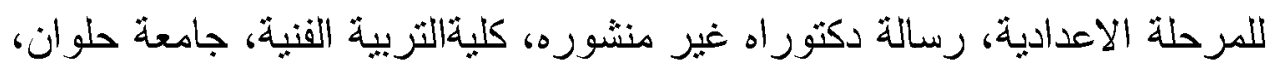
القاهرة:1990.

سعد الخادم: الصناعات الشعبية في هصر، دار المعارف، القاهرة، 1957.

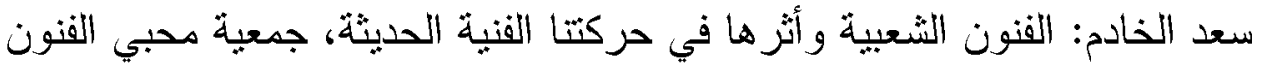
الجميلة، مطبعة نهضة مصر ، القاهرة، 1960. سعد الخادم: الدمي المنحركة عند العربن الدار القومية للطباعة والنشر، القاهرة

.1979

عبد الحميد يونس: دفاع عن الفولكلور، الهيئة المصرية العامة للكتاب، القاهرة $.19 \vee r$ عبد الحميد يونس: خيال الظل، الدكتبة الثتافية، مكتبة مصر القاهزة 1967. مصطفى الرزاز : مسرح خيال الظل: نراث المسرح، المركز القومي للمسرح و الموسيقى والفنون الثعبية، العدد I ، يوليو 2000 ، القاهزة. 
مصطفى الززاز واخرين: بانور اما فن الجر افيك المصرى فى القرن العشرين، مركز

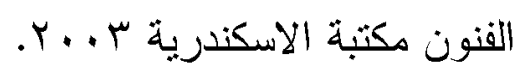

مصطفى الرزاز : الفن المصري الحديث: القرن العشرين، قطاع الفنون التشكيلية

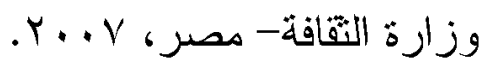

هحي الدين اللباد: الكتاب العربي المصور للأطفال، وجهات نظر العدد الخامس

$$
\text { و والخمسون، اغسطس 2002، الثروق، القاهرة. }
$$

هحمد عمر : حاضر المصريين أو سر تأخر هم، مطبعة المقتطف بمصر ، تحقيق مجيد اغيد

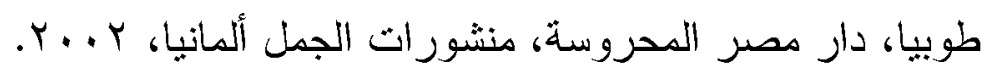

- Boardman John: Greek Art, Thames and Hudson, London 1996.

- Colin sexton: Art School, Chartwell Books Inc. New York 1999.

- Centlivres. Pierre\& Demont. MC: Imageries Populaires; en Islam, Georg, Geneve 1997.

- Strumikko Andrzej: Arabic Print, Project (5)- (102), Warszawa 1974 pp16-19.

- Lemaire Gerard Georges: The Orient in western art, Konemann2000.

- Kahel, paul E: The Arabic Shadow play in Medieval Egypt Journal of the Pakistan Historical Sociely Karachi 1954. 